\title{
The Netherlands Drawn from Life: An Introduction*
}

*Originally published as: Bakker, Boudewijn. "Nederland naar 't leven: Een inleiding." In Nederland naar 't leven: Landschapsprenten uit de Gouden Eeuw, 6-17. Zwolle: Waanders, 1993.

Boudewyn Bakker, Claire C. Whitner (translator)

boudewijn.bakker@planet.nl

clairewhitner@worcesterart.org

Recommended Citation:

Boudewijn Bakker, Claire C. Whitner (translator), “The Netherlands Drawn from Life: An Introduction*," Journal of Historians of Netherlandish Art 10:2 (Summer 2018) DOI: 10.5092/ jhna.2018.10.2.4

Available at https://jhna.org/articles/the-netherlands-drawn-life-introduction

Published by Historians of Netherlandish Art: https://hnanews.org/

Republication Guidelines: https://jhna.org/republication-guidelines/

Notes: This PDF is provided for reference purposes only and may not contain all the functionality or features of the original, online publication. This PDF provides paragraph numbers as well as page numbers for citation purposes.

ISSN: 1949-9833 


\section{The Netherlands Drawn from Life: An Introduction*}

*Originally published as: Bakker, Boudewijn. "Nederland naar 't leven: Een inleiding." In Nederland naar 't leven: Landschapsprenten uit de Gouden Eeuw, 6-17. Zwolle: Waanders, 1993.

Boudewyn Bakker, Claire C. Whitner (translator)

This essay examines the phenomenon of seventeenth-century Dutch landscape prints that were "drawn from life." The nascent national pride of the newly formed Republic, coupled with long-standing local traditions of cartographic and topographic representation, surely contributed to the sudden emergence of realistically portrayed printed landscapes. In addition, Italian Renaissance art theories that championed the scientific scrutiny of the visible world and the imitation of nature found a strong foothold in the Netherlands, where Karel van Mander and others extolled the practice of working from life. This model of artistic practice dovetailed with newly articulated Christian notions - expounded both by Reformed and Counter-Reformation thinkers - of the pious significance of studying and recording nature, understood as the visible manifestation of God's creation. This complex intersection of geographical heritage, newfound political independence and identity, scientific and art theoretical interest in imitation, and a strongly pious understanding of the natural world ultimately led artists to depict their native Netherlands "from life."

One of the most remarkable phenomena in the history of art is the unprecedented flourishing of the landscape in seventeenth-century Dutch painting, drawing, and printmaking. Contemporaries paid little attention to this occurrence at the time. Perhaps it seemed self-evident, or possibly too unimportant for comment.

2 That only changed in the nineteenth century. Especially in France, artists from the Realist and later the Impressionist school were greatly influenced by the discovery of the recognizable, or at least convincing-looking, landscapes of their remote Dutch predecessors. They were likewise the first people to call seventeenth-century Dutch painting "realistic." In the tradition of the French painters and art critics, later art historians have long assumed it to be more or less self-evident that the earlier landscape artists from Holland in essence strove to achieve the same thing French artists would two centuries later. The Dutch artists may not have literally painted in accordance with the French nineteenth-century ideal of "en plein air," but they certainly sought in the studio to transfer to canvas, panel, or (for reproduction) copper plate the impressions they had recorded in nature as accurately as possible. Furthermore, they would have just simply followed their natural instinct, like the French in the nineteenth century, in order to imitate reality as precisely 
as possible, without involving afterthoughts or associations.

3 For more than two decades, a lively discussion has gone on regarding this development, which was set in motion above all by an article by E. de Jongh from 1971, in which "realisme" (realism) was distinguished from "schijnrealisme" (seeming realism). ${ }^{1}$ De Jongh asserted that the seventeenth-century landscape artists did not intend-like their later French admirers-to render a specific location at a particular moment, but that, as a rule, they instead wanted to paint landscapes that could make as naturalistic an impression as possible: not landscapes just as they appeared, but rather as they could exist. Over time, De Jongh's perspective convinced most art historians. In the meantime, hardly any further discussion on the topic has arisen. New contributions continue to appear in which De Jongh's position is implemented, expanded, or illustrated with new examples. ${ }^{2}$ Gradually "realism" in its original meaning has almost completely disappeared in favor of "seeming realism." Most authors now accept as absolute fact that the artists of the seventeenth century did nothing more than combine and arbitrarily edit elements of reality with the purpose of creating a new seeming-reality.

At the same time, in the past few years another discussion has arisen with regard to whether other meanings are perhaps hidden beneath the visible surface of landscape representations. ${ }^{3}$ Although both areas of discussion certainly exhibit points of contact, this essay is devoted exclusively to the degree of reality reflected in the seventeenth-century landscape, with an emphasis on prints.

5 In the first place, it aims to determine the actual subject of these deceptively "authentic-" appearing landscapes, and the extent to which the artist allowed himself to manipulate reality for the benefit of the artwork. Lastly, the extent to which the artist was guided by aesthetic theories and philosophical considerations will be examined. For such research, prints, rather than paintings, offer great advantages. Landscape prints include a heading or subtitle more often than paintings, and additionally they were frequently published in series with a title page. Headings and titles can often help with establishing the intended or actual subject of the representation. Moreover, they can impart something about the intended function of the edition.

An interesting detail in this regard is that title pages often include statements along the lines of naar 't leven or "from life," that is to say, from actuality or from nature. A second detail is that a great number of prints and print series mainly (or only) render landscapes in the Dutch Republic, which was often referred to as Nederland-The Netherlands. The prints discussed here were all chosen from the vast, comprehensive group of Dutch landscapes, to the exclusion of Southern Netherlandish, Italian, and other more exotic landscapes. This choice was motivated by the need to limit the enormous terrain of landscape graphics, but even more than that by the question of why Dutch artists at the time so often chose their own country as their subject.

\section{The Netherlands}

In 1596 the kings of France and England arranged a treaty with the Republic of the United Netherlands, which was then only fifteen years old. With this, the union of the northern Netherlandish regions that had risen up against Spain was given de facto recognition internationally as a nation state. In 1609, Spain itself followed with the signing of the Twelve Years' Truce, through which the 
existence and the physical extent of the Republic were recognized.

8 The core of this federal state comprised the provinces of Holland, Zeeland, Utrecht, and Friesland (fig. 1, cat. 1). Although the original number of rebellious provinces was much larger, in the first decades after 1568 most of them were conquered by the Spanish. Meanwhile Maurice of Nassau succeeded his father, the Stadholder William of Orange. Under the leadership of this clever general, the provinces of Groningen, Drente, Overijssel, and Gelderland were recaptured from the Spanish (fig. 2, cat. 11). Strategically speaking, these provinces formed a broad and important defensive belt on the eastern side of the core territory. The great rivers formed the southern defense line. The areas to the south, that is, present-day North Brabant, Limburg, and Zeelandic Flanders, were still under Spanish control in 1609.

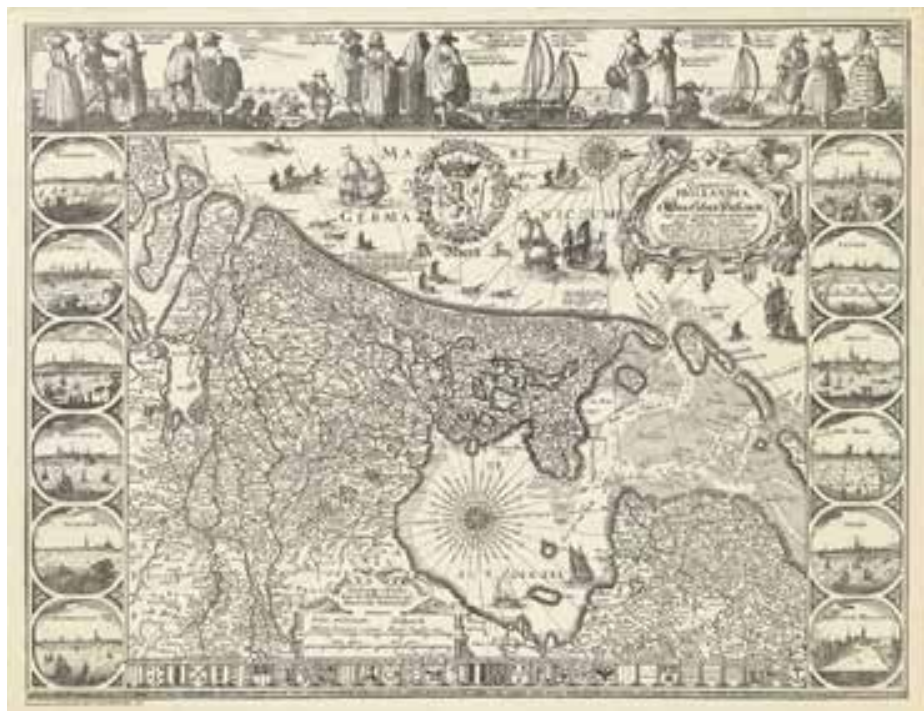

Fig. 1 Cat. 1, Josua van den Ende, (Amsterdam ca. 1584-after 1634 Amsterdam), Claes Jansz Visscher, (Amsterdam 1587-1652 Amsterdam), Figurative Map of Holland, 1608, engraving (map) and etching (border decorations and cartouche)

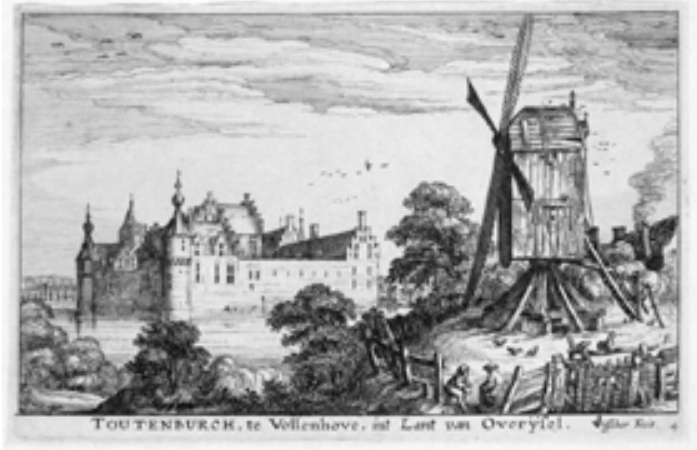

Fig. 2 Cat. 11, Claes Jansz Visscher, (Amsterdam 1587-1652 Amsterdam), Castle Toutenburg at Vollenhove, 1617, (from a series of four prints with medieval castles), etching, second state (2)

After the expiration of the Twelve Years' Truce in 1621, Stadholder Frederick Henry captured a number of military footholds in a series of campaigns in the provinces that had remained part of Spain, specifically Flanders, Brabant, and Limburg, (figs. 3, 4, cats. 12, 55), among which Maastricht was the farthest south. At the Peace of Munster in 1648, the official end of the Eighty Years' War, these cities and strongholds, together with the surrounding countryside, were recognized as belonging to the Republic. They remained, however, "Generality Lands," regarded and treated as subjugated territory under direct control of the national government. They served primarily as southern military buffer zones around the Scheldt and the Maas. 

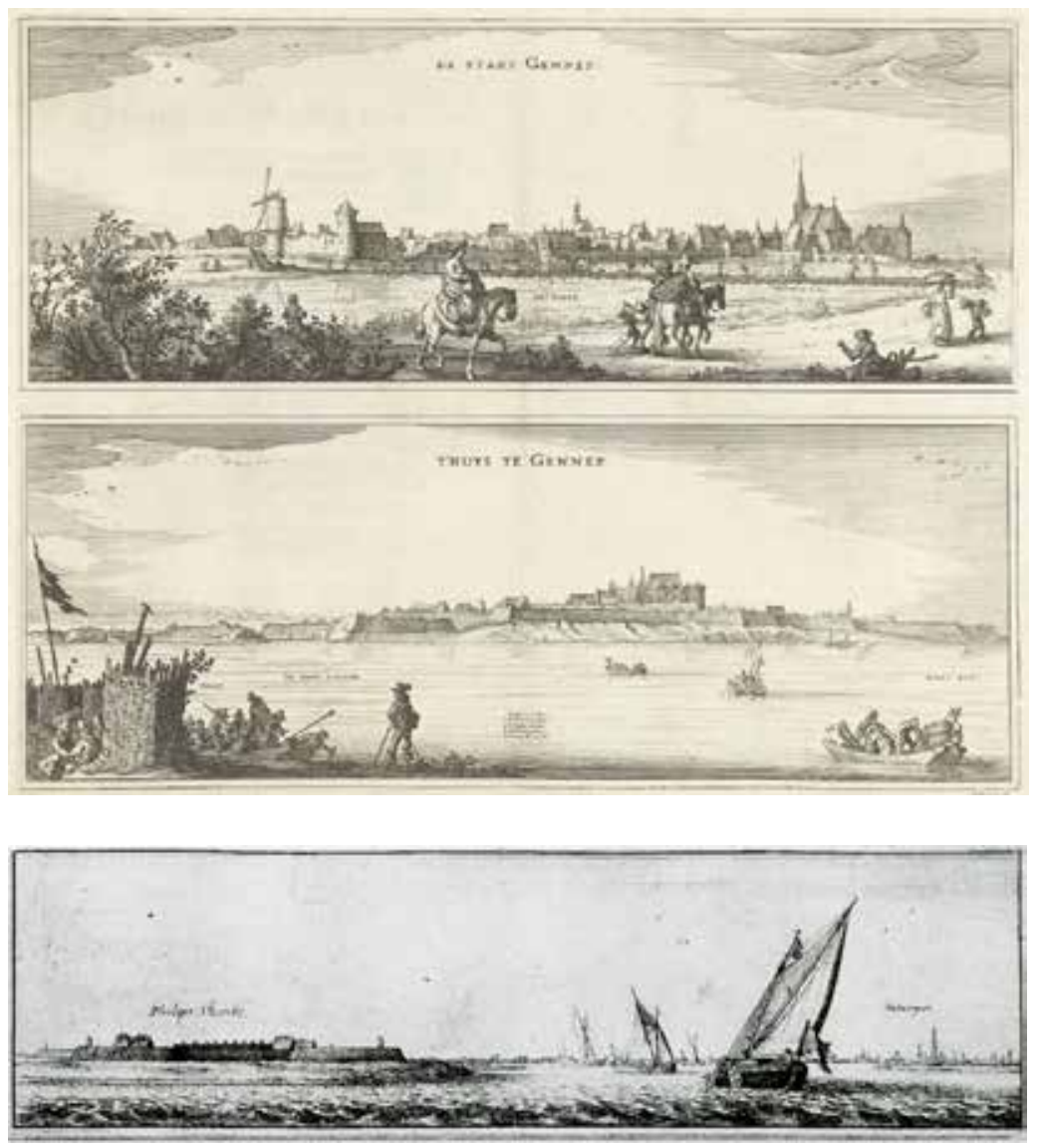

Fig. 3 Cat. 12, Claes Jansz Visscher, (Amsterdam 1587-1652 Amsterdam), View of the (ity and the Castle Gennep, 1641, two etchings on one plate, single state

Fig. 4 Cat. 55, Wenceslas Hollar, (Prague 1609-1677 London), Philippine, ca. 1650, etching, second state (3)

Originally, the name Nederland was used to refer to the whole area of the Low Countries, thus for all Belgian as well as Dutch territories, including those farthest south. Since the beginning of the seventeenth century, however, this name has usually been reserved for the area of the Republic.

11 From the very beginning, Holland was the richest and most powerful province. Maps of the Republic's core area, which after 1600 began to appear in abundance as a sign of growing self-awareness, always bore the name of Holland, even though they also largely depicted the other three core provinces around it-Zeeland, Utrecht, and Friesland (see fig. 1, cat. 1). Only in the 1640s, during the negotiations for the Peace of Münster did the Amsterdam master cartographer Joan Blaeu begin to compile a book of maps from the whole Republic, including the border areas in Brabant and Zeeland. This book was published in 1664 as part of the Atlas Major with the title 't Vereenighde Nederlandt (The United Netherlands). ${ }^{4}$

12 Whoever carefully studies these maps and compares them with other information will discover that the territory of the Netherlands at that time was characterized by a great diversity of types of landscape-as it still is. They will also discover a high degree of inconsistency in the landscapes. The whole country was constantly under heavy pressure. This was caused in the first place by the vicissitudes of a war that had lasted nearly a century, as a result of which the borders were constantly being shifted and the provinces on the periphery were ravaged again and again by devastation and plunder. In addition, the forces of nature exerted an impact on the landscape that was as drastic as that of human interventions. ${ }^{5}$ 
Around 1600, Holland north of Amsterdam and Haarlem still consisted largely of water. The ocean and the large lakes perpetually consumed the poorly sheltered land in between. Also, during storms along the North Sea coast, portions of the dunes would be lost. Such fishing communities as Egmond aan Zee, Petten, and Zandvoort led a permanent and sometimes desperate battle against the sea (figs. $5 \mathrm{a}, 6$, cats. $8 \mathrm{a}, 10$ ). Large parts of Zeeland were under water for decades, caused by both natural floods and deliberate inundations during wartime (fig. 7, cat. 57). Human influences also contributed to the degradation of the territory. In the moorland of South Holland and Utrecht, a vast region of wetlands developed as a result of dredging the moors to obtain peat, which offered a cheap source of fuel for a growing urban population. In the past, the great forests in the region had been heavily depleted for various reasons. The majority of them had already been chopped down in the sixteenth century for the construction industry and fuel supply. The last tree in the famous Gooi Forest was felled in 1699. The Rijkswald Forest south of Nijmegen suffered badly as well. Cheap wood from Scandinavia and the growing production of peat made the maintenance and cultivation of forests less economically compelling (fig. 8, cat. $60)$.

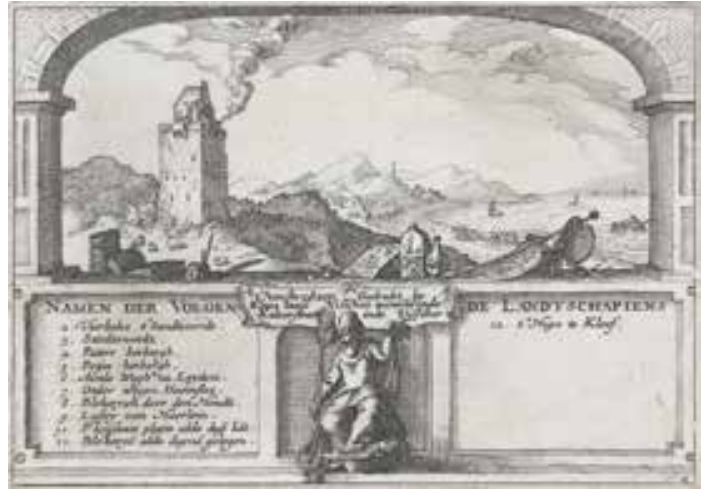

Fig. 5a Cat. 8a, Claes Jansz Visscher, (Amsterdam 1587-1652 Amsterdam), The Lighthouse at Zandvoort, ca. 1611-14, etching, single state

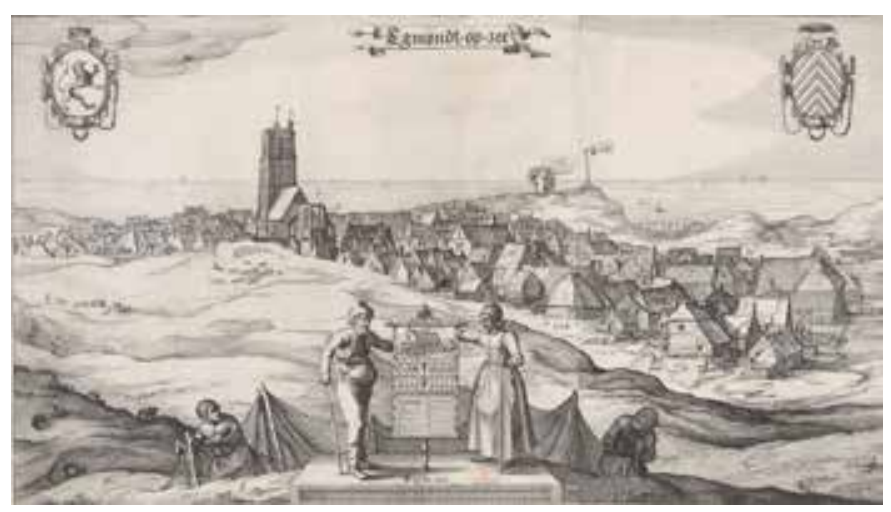

Fig. 6 Cat. 10, Claes Jansz Visscher, (Amsterdam 1587-1652 Amsterdam), View of Egmond aan Zee, ca. 1615, etching and drypoint, single state

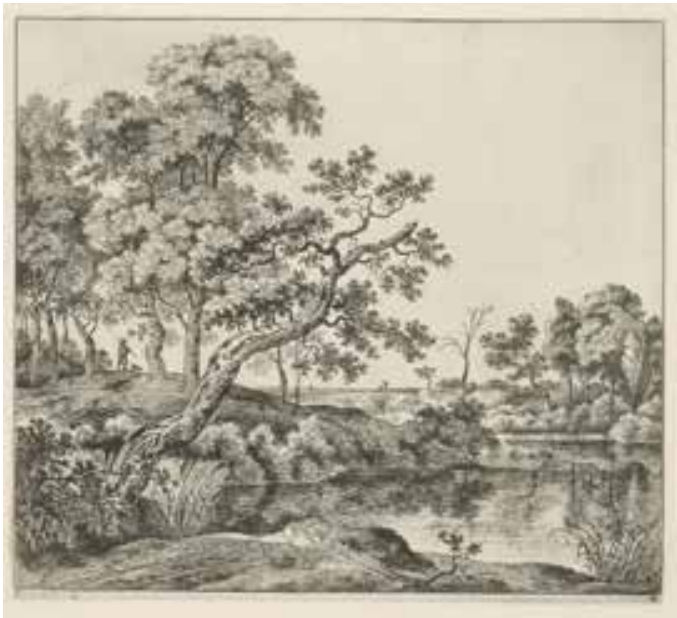

Fig. 8 Cat. 60, Jan Hackaert, (Amsterdam 1629-after 1685 Amsterdam?), Forest Landscape with Travelers, ca. 1650-60, etching, second state (2)
Fig. 7 Cat. 57, Reinier Nooms, called Zeeman, (Amsterdam ca. 1623-1667 Amsterdam), Flooded land in Zeeland, ca. 1656, etching, first state (3) 
The sand drifts that made vast stretches of the deforested dune areas and the Veluwe uninhabitable posed another problem. They also threatened the agricultural land in those areas. Together with the reoccurring military disturbances, they ensured that dozens of villages, particularly in the eastern provinces, were abandoned, sometimes for good (figs. 9, 10, cats. 53, 54). Moreover, the higher and therefore purportedly drier part of the Netherlands stayed very wet due to the absence of the sort of hydraulic works established in the west. For the most part, the border provinces of Drente and Overijssel as well as East Groningen comprised barely penetrable badlands (figs. 11, 12, cats. 43, 46). On Blaeu's map, the whole area between Coevorden and the Dollard is indicated as "a large swampy moor." As long as the war continued, North Brabant and North Limburg, too, contained considerable moorland and swamp that remained uncultivated for strategic reasons.

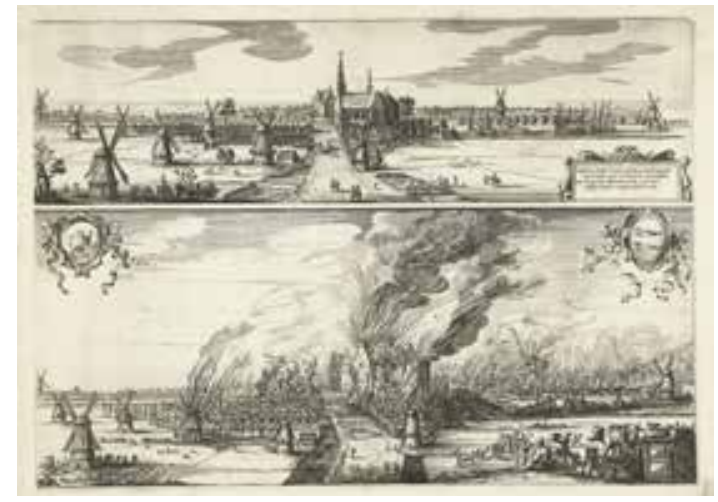

Fig. 9 Cat. 53, Salomon Saverij, (Amsterdam 1594-1678 Amsterdam), De Rijp before and during the Fire of 1654, ca. 1657, etching, single state

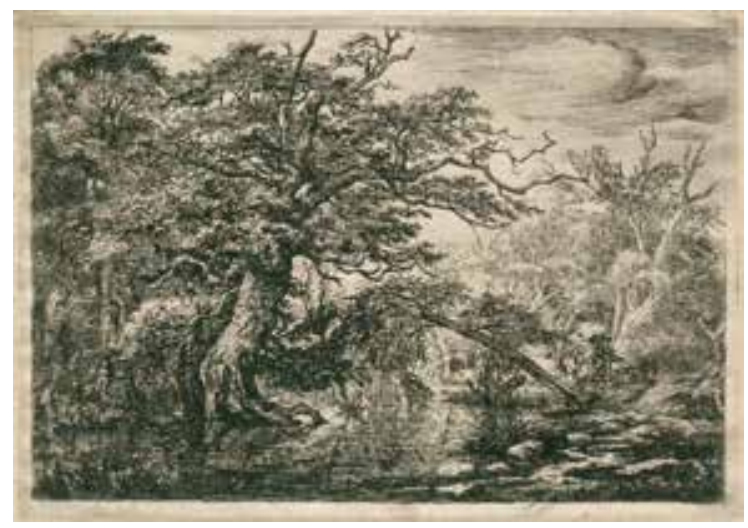

Fig. 11 Cat. 43, Jacob van Ruisdael, (Haarlem 1628/29 -1682 Amsterdam), Travelers in a Forest Marsh, 1650-55, etching, fourth state (4)

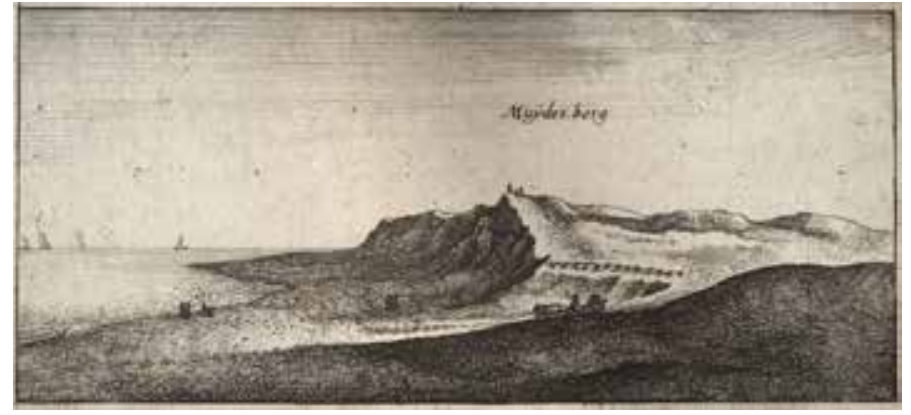

Fig. 10 Cat. 54, Wenceslas Hollar, (Prague 1609-1677 London), Muiderberg, ca. 1643 , tching, single state

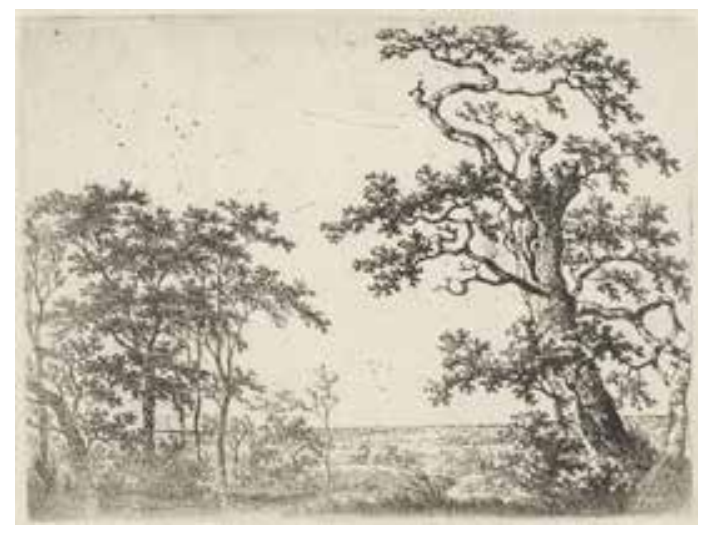

Fig. 12 Cat. 46, Adriaen Verboom, (Rotterdam ca. 1628-ca. 1670 Amsterdam?), Trees in a Bog, ca. 1663, etching, first state (3)

On the other hand, a variety of human-generated activities were developed to gain new land or reclaim existing areas. First were the spectacular polders. Most of North Holland and various South Holland lakes were pumped dry and prepared for agriculture. Additionally, large areas of land outside the dikes in Groningen and the north of North Holland and along the South Holland and Zeeland estuaries were captured for the first time (or again) from the sea by means of 
embankments. In the South Holland regions of Amstelland and Rijnland, many existing polders were drained and irrigated more thoroughly. Here and there in Holland and Utrecht, attempts were made to pump out the lakes caused by digging peat, simultaneously with the large-scale reclamation projects targeting the peat marshes in Groningen and in the Gelderse Vallei between Utrecht and Gelderland.

After 1648, the abandoned agricultural areas in the east were slowly brought back into use, but only in the last quarter of the century did Stadholder William III and other members of the landed gentry begin systematically to plant woods in Gelderland and Utrecht. In the meantime-beginning in the late Middle Ages - the interior parts of the dune region along the coast of Holland were slowly leveled off in strips and made more suitable for agriculture, especially for horticulture, to supply the Dutch cities. The Zaan district, as well as-on a smaller scale-the countryside directly outside the big cities, developed into an area of windmill industry. And lastly, countless existing waterways were connected and new ones excavated to facilitate fast and efficient transport. This benefited the newly established networks of towboat canals in the western and northern provinces in particular.

The young nation's territory was thus subject to several different influences, each reinforcing the other. The already richly varied landscape continued to change in character and appearance, especially during the first half of the century. At the same time, the political identity of the Republic grew more and more stable as the century progressed. The question is now how artists responded to this.

\section{From Life}

18 In the period from 1610 to 1620 , a remarkable phenomenon came to light in the art world of the Netherlands. In Amsterdam and Haarlem, several print series appeared suddenly and independently of each other. They either clearly declared that they offered views of specific locations around both of these cities or displayed landscapes that could be definitely encountered in Kennemerland, Amstelland, or elsewhere in Holland and Zeeland (figs. 13, 14a and 14b, 5a and 5b, 15a-d, 16a and 16b, 17a and 17b, cats. 5, 6a and b, 8a and b, 9a-d, 15a and b, 17a and b). They represent the beginning of the production of the many Dutch landscape print series that would follow in the course of the century. The remarkable fact of this sudden appearance has been pointed out more than once. Scholars have sometimes observed that these series were possibly the expression of the pride that artists, publishers, and collectors from Holland felt for their own country and in particular for their own province. It is indeed remarkable that these first series of more or less topographic prints were published in the decade after the settlement of the Twelve Years' Truce of 1609, wherein Spain officially recognized the Republic as an independent power. This phenomenon was thus strongly reminiscent of the circulation of the exquisite "figurative" maps of Holland and the Republic in the first decade of the century (see fig. 1, cat. 1), shortly after Maurice's conquests. These maps were in part produced and published by the same people as the creators of the later topographic series. 

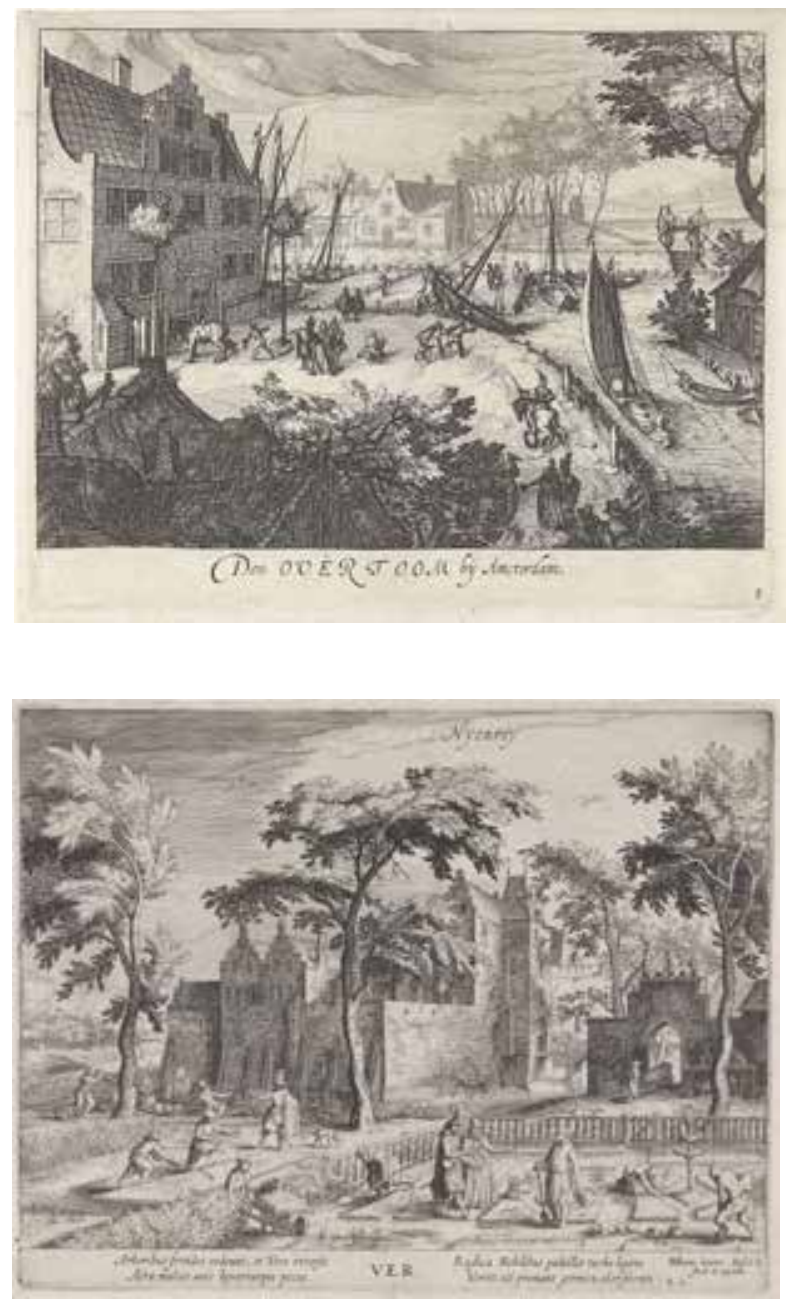

Fig. 14a Cat. 6a, Hessel Gerrits, (Alkmaar 1581-1632 Amsterdam), After David Vinckboons, (Mechelen 1576-1633 Amsterdam), Two Landscapes with Castles, Nijenrode ("Ver"),etching, first state (2)

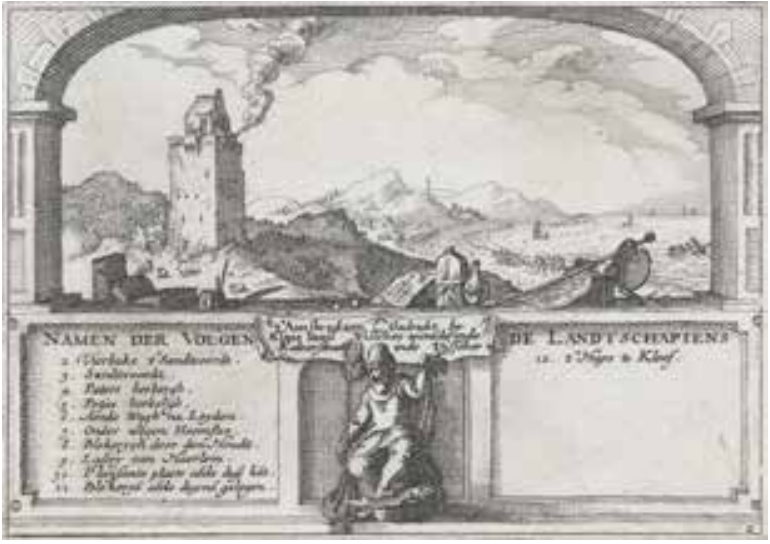

Fig. 5a Cat. 8a, Claes Jansz Visscher, (Amsterdam 1587-1652 Amsterdam), The Lighthouse at Zandvoort, ca. 1611-14, etching, single state
Fig. 13 Cat. 5, Simon Wynants Frisius, (Harlingen? ca. 1580-1629 The Hague), The Overtoom near Amsterdam, ca. 1650, etching, first state (3)

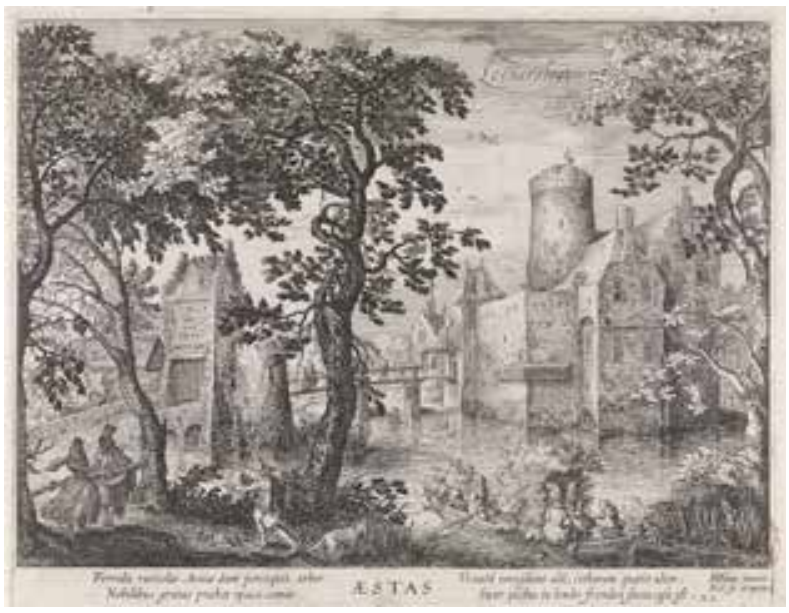

Fig. 14b Cat. 6b, Hessel Gerrits, (Alkmaar 1581-1632 Amsterdam), After David Vinckboons, (Mechelen 1576-1633 Amsterdam), Two Landscapes with Castles, Loenersloot ("Aestas"), etching, first state (2)

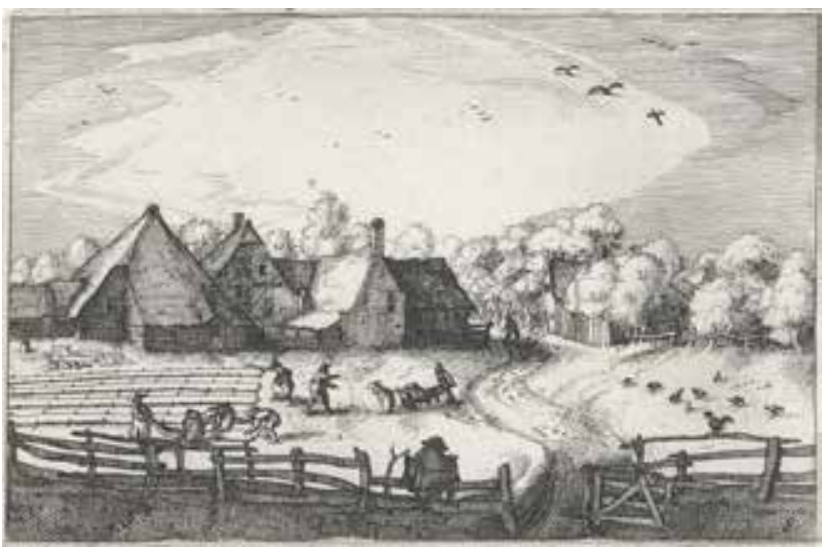

Fig. 5b Cat. 8b, Claes Jansz Visscher, (Amsterdam 1587-1652 Amsterdam), Bleaching Fields near the Haarlemmer Hout, ca. 1611-14, etching, single state 


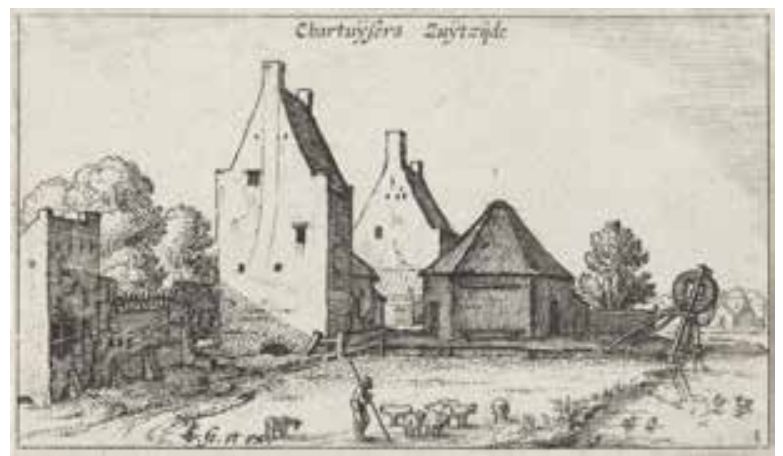

Fig. 15a Cat. 9a, Claes Jansz Visscher, (Amsterdam 1587-1652 Amsterdam), Four Views outside of Amsterdam, The Karthuizer Klooster (Cartusian Convent), ca. 1610, etching, single state

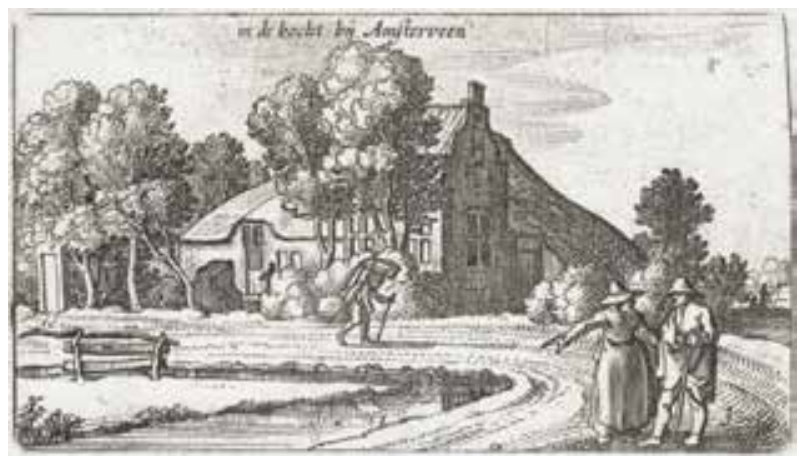

Fig. 15c Cat. 9c, Claes Jansz Visscher, (Amsterdam 1587-1652 Amsterdam), Four Views outside of Amsterdam, The Bend in the Road to Amstelveen, ca. 1610, etching, first state (2)

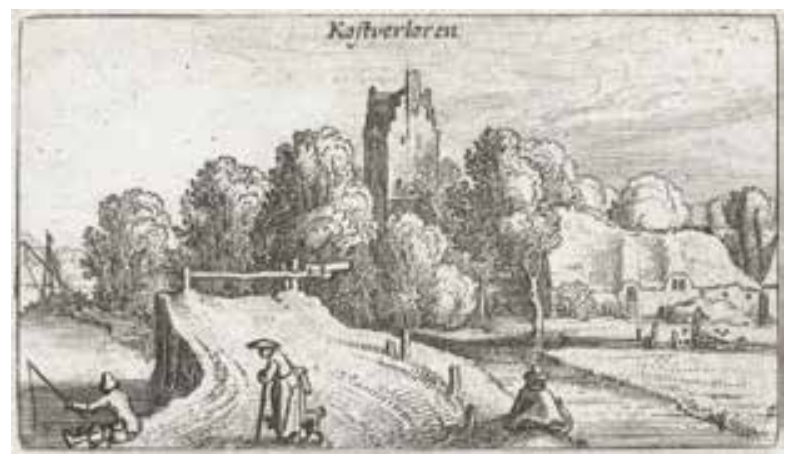

Fig. 15b Cat. 9b, Claes Jansz Visscher, (Amsterdam 1587-1652 Amsterdam), Four Views outside of Amsterdam, The Amsteldijk by Kostverloren, ca. 1610, etching, first state (2)

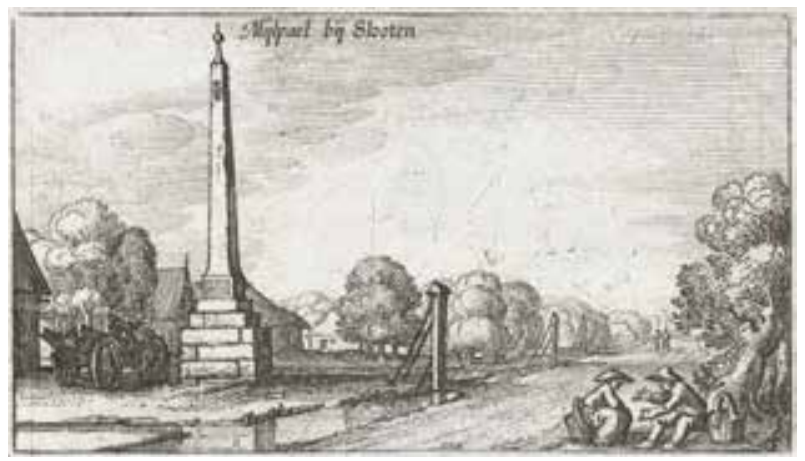

Fig. 15d Cat. 9d, Claes Jansz Visscher, (Amsterdam 1587-1652 Amsterdam), Four Views outside of Amsterdam, The Mile Marker at Sloten, ca. 1610, etching, first state (2)
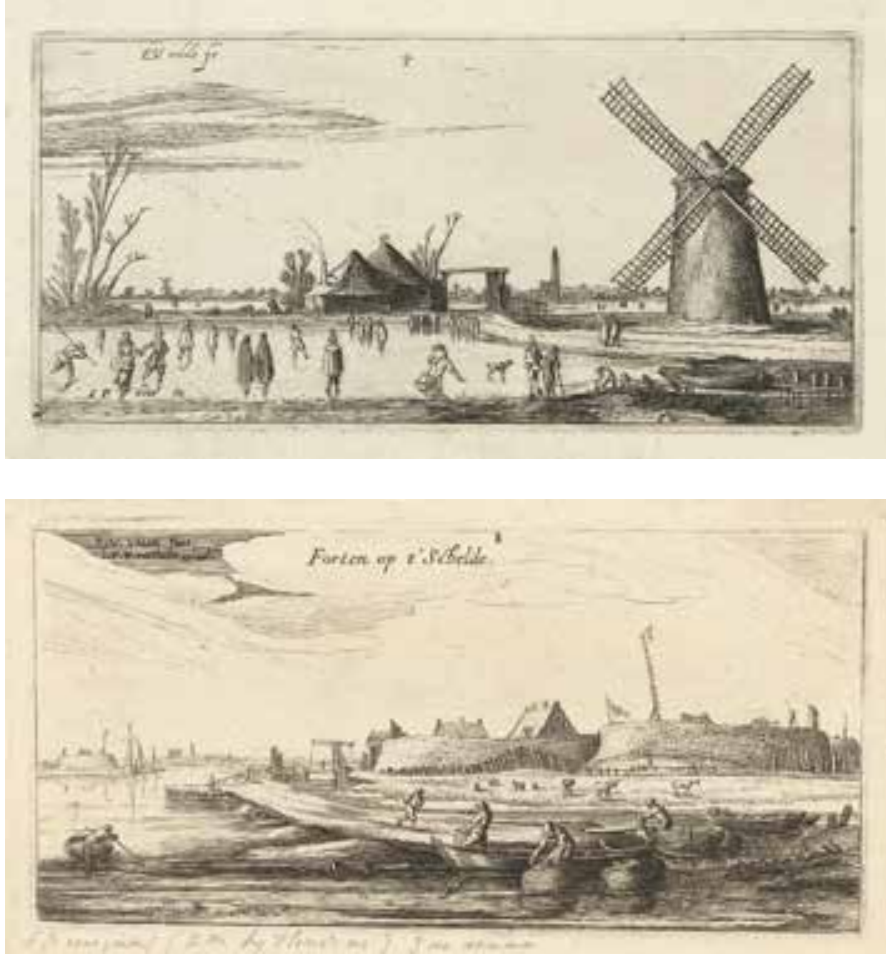

Fig. 16a Cat. 15a, Esaias van de Velde, (Amsterdam ca. 1590 -1630 The Hague), Skaters on the Ice at a Mill near Penningsveer, 1615-16, etching, first state (4)

Fig. 16b Cat. 15b, Esaias van de Velde, (Amsterdam ca. 1590-1630 The Hague), Fort on the Scheldt, 1615-16, etching, second state (4) 


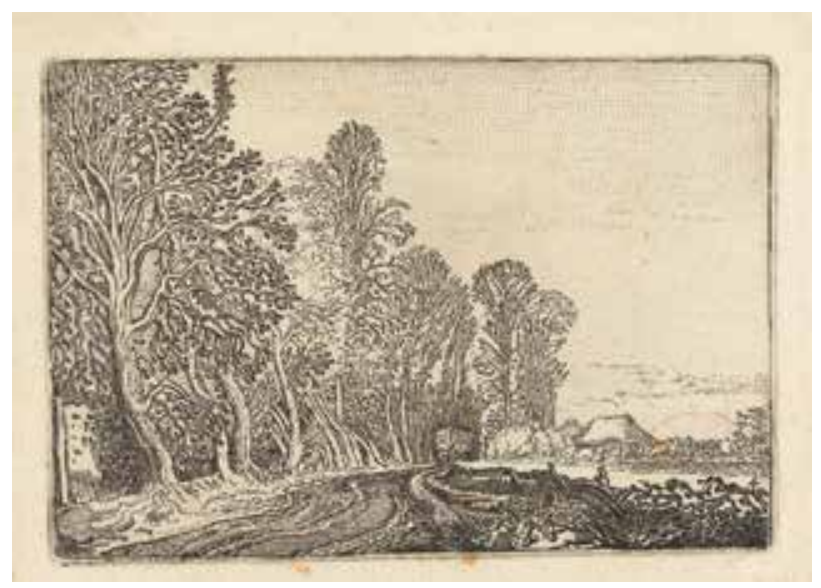

Fig. 17a Cat. 17a, Willem Buytewech, (Rotterdam 1591-1624 Rotterdam), Landscape with Trees, a Path, and a Wagon, ca. 1616-17, etching, third state (3)

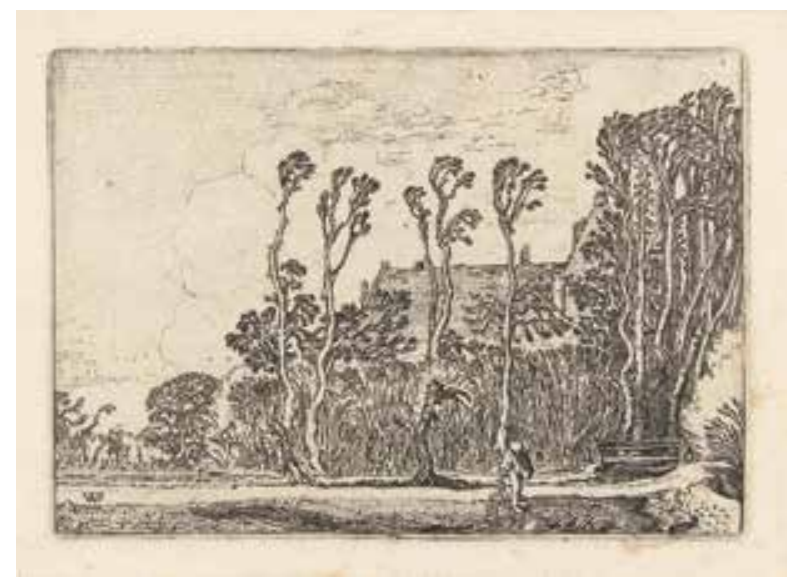

Fig. 17b Cat. 17b, Willem Buytewech, (Rotterdam 1591-1624 Rotterdam), The Sower, ca. 1616-17, etching, third state (3)

On the figurative maps, the area's actual layout was combined with illustrations of cities, regional dress, professions, and enterprises, as well as historic occurrences. The maps make clear how closely the production of geographic cartography was bound to the production of city and landscape portraits. ${ }^{6}$ To understand this phenomenon, we have to return in time to a period at least one and a half centuries earlier. In the Middle Ages, Flanders, Zeeland, and Holland were already heavily populated and highly developed regions with complex hydraulic engineering construction. The control of these areas required a method for demonstrating ownership and a trustworthy administration. The long and strong tradition of land measurement and cartography in the Netherlands can be explained by this history. It is no wonder that the art of triangulation, which laid the foundation for modern cartography, was developed at the University of Leuven.

The oldest mapmakers were accustomed to rendering the represented area more or less as a two-dimensional field. Villages, cities, or distinctive buildings, however, appeared on them not in the abstract form of a floor plan, but in the more illustrative form of profile views or even three-dimensional portraits. Mapmakers were thus simultaneously both surveyors and illustrators. Even in the sixteenth century, it was not unusual for a painter to work as a cartographer. Cornelis Anthonisz from Amsterdam is best known as a portraitist, but he is also the creator of the famous "bird's-eye plan" from 1539, in which he depicted his city in accordance with the then-modern method of triangulation. For the buildings, he proceeded-like all cartographers before him-from drawings that he had made in situ. No drawings by Cornelis Anthonisz have been preserved, but he must have been skilled in the technique of topographic drawing.

21 Pieter Bast, who was active a half century later, produced maps as well as views of cities that he sometimes adapted into Biblical or allegorical scenes (figs. 18, 19, cats. 2, 3). Claes Jansz Visscher, the creator and publisher of the renowned series Plaisante Plaetsen (Pleasant Places), among others, had probably also experienced a very broad training (figs. 5a, 5b, cats. $8 \mathrm{a}$ and b). Initially, he etched landscapes with narrative scenes after work by other artists. In addition, he worked as an illustrator of figurative maps. Concurrently in his sketchbook, he drew views "from life" in the areas surrounding Haarlem and Amsterdam, which he later published in print form. The views of 
the dunes in the series Plaisante Plaetsen (fig. 18, cat. 2) join seamlessly with his panorama on the figurative map of Holland by Willem Jansz Blaeu (see fig. 1, cat. 1). As a publisher, he focused on maps, topography, and landscapes that he and other masters created (e.g., figs. 19, 17a and 17b, 20 , cats. $3,17 \mathrm{a}$ and $\mathrm{b}, 20$ ).

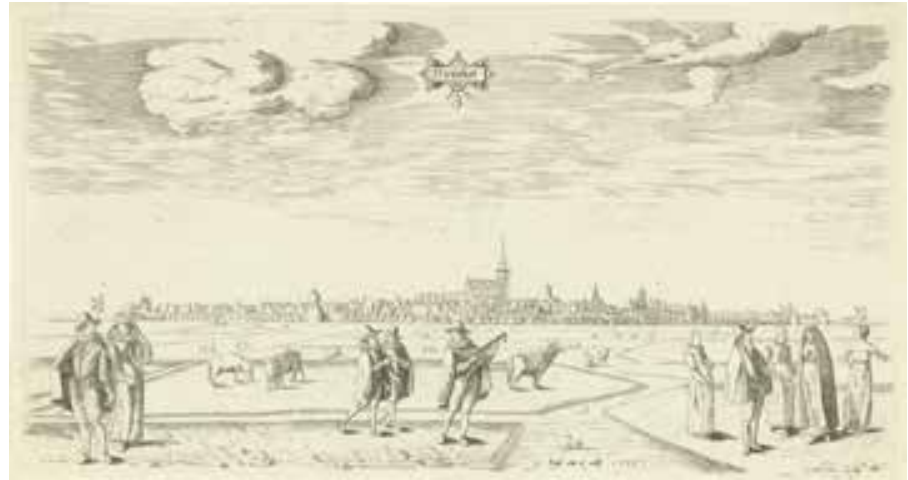

Fig. 18 Cat. 2, Pieter Bast, (Antwerp ca. 1570-1605 Leiden), Profile of Franeker from the Northeast, 1598, engraving, single state

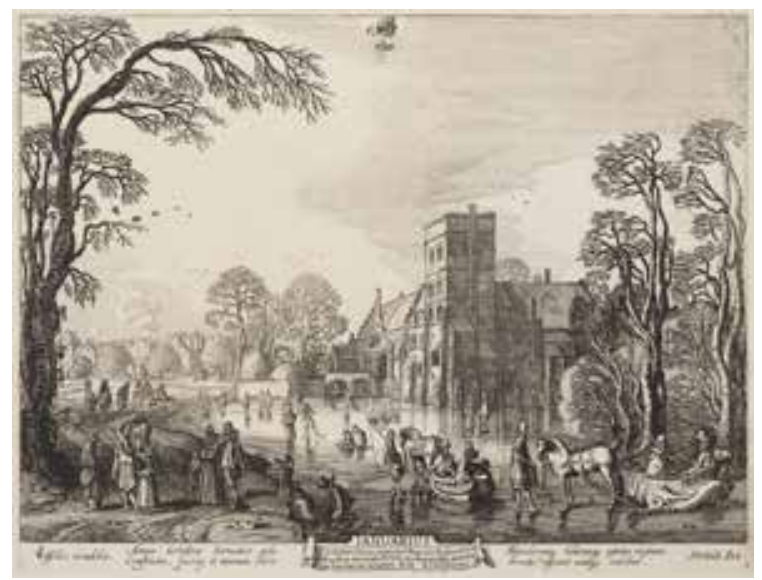

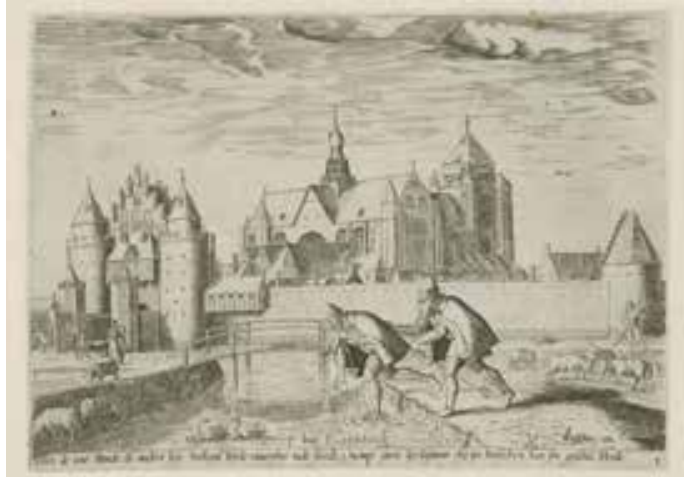

Fig. 19 Cat. 3, Pieter Bast, (Antwerp ca. 1570 -1605 Leiden), Two Blind Men with a View of Veere in the Background, 1598, engraving, second state (2)
Fig. 20 Cat. 20, Jan van de Velde II, (Delft? 1593-1641 Enkhuizen), View of the Hofvijver in The Hague (January), 1618, etching, single state

The unusual aspect of the topographical series mentioned above is not that their makers were able to draw them easily or that they spent time on these kinds of subjects at all. This practice had been in place for umpteen generations. But it is noteworthy that they released their drawings as independent works of art in print form. In some cases, that can be clarified (as mentioned previously) by the increasing importance that the Dutch placed on their own-now literally-country. It is even possible to see in the printed figurative maps, city views, and the series of topographic prints, a bourgeois sequel to the practice among sovereigns in the sixteenth century to commission artists or topographers to depict the most distinguished locations in their region in the form of series of paintings, tapestries, and frescoes with maps and city panoramas. The finest example in this context is that of the painter Antoon van de Wijngaerde, who was commissioned by King Philip II to draw and paint the Netherlandish cities.

23 Not only professional cartographers studied how to draw landscapes "from life." Artists had also followed this practice for a long time, that is, artists who focused on painting biblical or ancient history subjects that were set in a landscape, which they had to invent or compose themselves. In 
his Schilderboek from 1604, the Haarlem painter Karel van Mander advised young artists to get up early: "and come see the beauty that is outside / where beaked, wild musicians [birds] flute / there we will espy many views / that will serve us in creating landscapes."

24. Van Mander was referring to a practice that had been in place since the Renaissance, or at least had been propagated that early in theory. The artist was obliged to practice rendering human figures as well as animals, plants, and landscape motifs, so that he could later implement them convincingly when realizing a composition of his own invention on canvas or panel. This was also the manner in which Pieter Bruegel worked.

Nevertheless, not all artists were equally diligent in drawing from nature. Some did not allow enough time for it or simply did not like it. Such artists sometimes hired landscape specialists to fill in a background or "verschiet" (view into the horizon) in their painting. They could also make use of reproductive prints made after older works of art, or drawings of landscape motifs by other artists, which was less expensive. Enterprising artists also began to publish their own drawings or those of others in the form of print series for the benefit of colleagues. Around 1550, the first print series exclusively comprising landscape motifs appeared in the Netherlands. The many dozens of prints featuring Roman ruins issued by the Antwerp publisher Hiëronymus Cock in 1550 and afterwards were initially intended for the studios of artists who had not personally visited Rome. The Latin title of one of these series refers to them as "typographicae adumbrationes, in publicum pictorum usum a Hieronimo Cock delineatae" (sketches that were drawn by H. Cock and circulated in print for the benefit of painters). ${ }^{8}$

Cock also published two series of "sketches of farmhouses, cottages, and estates, accurately drawn from life" in 1559 and $1561 .^{9}$ These became famous among art historians, because they comprise the first Netherlandish landscape prints without the addition of a biblical subject or other narrative message. Around fifty years later, in 1612, Claes Jansz Visscher partially copied and republished the popular series. ${ }^{10}$ On the title page, he printed an inscription in Latin in which the original drawings are attributed to Pieter Bruegel. This title also includes the phrase "in pictorum gratiam" (for the convenience of artists). This can mean nothing less than that Visscher published the series of Brabant village scenes with the intention of having them serve as a resource and example for the aforementioned history painters, who were less talented with landscapes. The original series Kleine landschappen (Small Landscapes) by Cock must have also initially functioned-just like his "Roman ruins" and the copies by Visscher-as a treasure trove or reservoir of landscape motifs.

27 Visscher's publication did not exist in isolation. In 1616, the Haarlem publisher Robert de Baudous issued a series of sixteen etched landscapes by Jan van de Velde. ${ }^{11}$ Presumably drawn from life, most depicted ruins, with which Kennemerland was richly provisioned after the terror of Spanish troops. According to the title print, these landscapes were intended "ad oculorum oblectamentum et Picturae adjumentum" (for the entertainment of the eyes and a painting resource).

The prints of the Utrecht painter Abraham Bloemaert, who was among the most renowned Dutch artists in the period around 1600, are interesting in this context. Karel van Mander reports about Bloemaert that he "seer veel nae t' leven doet," (often draws from nature), especially farmhouses, 
farming equipment, trees, and fields (figs. $21 \mathrm{a}$ and $21 \mathrm{~b}$, cats. $7 \mathrm{a}$ and b). He used these drawings primarily as preparatory material for his own painted landscapes with narrative subjects. But around 1600 he began to exploit his enormous inventory of sketches by publishing them as print series.

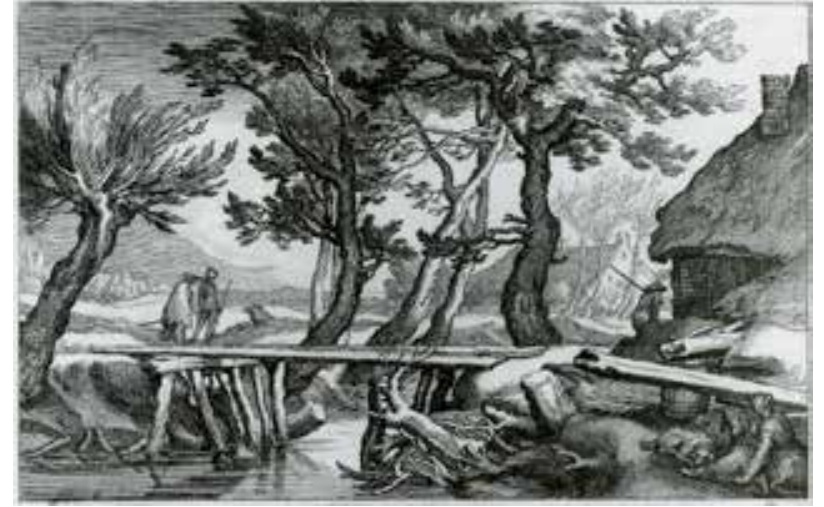

Fig. 21a Cat. 7a, Boëtius Adams Bolswert, (Bolsward 1580-1633 Antwerp), After Abraham Bloemaert, (Gorinchem 1564-1651 Utrecht), Two Views of the Environment in the Vicinity of Utrecht, Village View in the Fen, 1613-14, etching, first state (2)

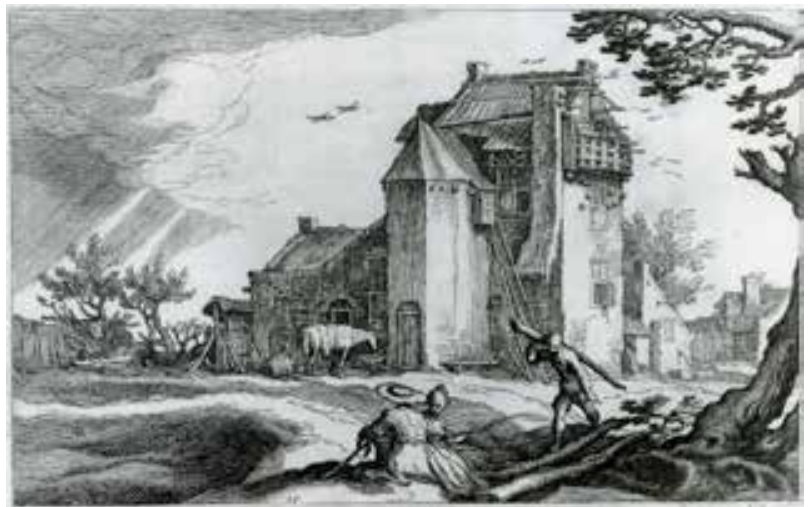

Fig. 21b Cat. 7b, Boëtius Adams Bolswert, (Bolsward 1580-1633 Antwerp), After Abraham Bloemaert, (Gorinchem 1564-1651 Utrecht), Two Views of the Environment in the Vicinity of Utrecht, Homestead on the Dunes, 1613-14, etching, first state (2)

The largest series is called Het tekenboek van Abraham Bloemaert (Abraham Bloemaert's Sketchbook), which comprises 120 etchings with picturesque motifs. ${ }^{12}$ The total number of etchings after motifs drawn by Bloemaert approaches 300 . Some of the more ambitious prints include narrative elements and thus could also be enjoyed as independent works of art in the traditional sense. Most, however, are nothing more than Northern Netherlandish variants of the Kleine landschappen (Small Landscapes) by Hiëronymus Cock, without any human or animal staffage. At least originally, these were almost certainly intended for artists. The many different series and the repeated reprints and copies, make it clear that after circa 1600, in addition to the originally intended customers, a new market was emerging among fans of simple landscape subjects "from life," without narrative content.

30 This new demand from a new public was met by artists who worked in two different traditions. On the one hand, the cartographer/topographer focused on depicting an actually existing entity with scientific precision. On the other hand, the freely inventive artist worked in the manner that had been in fashion all over Europe since the Renaissance. Claes Jansz Visscher belonged to the first tradition, Abraham Bloemaert to the second. In both cases, the end result was founded on the accurate examination of nature in her elements, at least in the Netherlands.

31 One could also ask what gave rise at the beginning of the seventeenth century to this high demand for a new type of artwork that offered scarcely more than what previous generations had regarded as a half-finished product. In part, the explanation can be sought-as has already been indicated above-in the fact that around 1600, a new generation grew up in the cultural capitals of the young Republic. For the first time, after roughly thirty years of uncertainty and hardship, these people got the opportunity—and they seized it— to look around peacefully and become aware of the land that their parents had wrested from the enemy. That land was now theirs. 
32 If we adhere to this assumption and project it later into the century, it becomes more understandable that in the 1640s, when the war had in fact ended and the reconquest of the peripheral areas had occurred, a new generation moved about in the country and discovered new landscape elements of their homeland: the great rivers, the Utrecht hills, the forests of the Veluwe and around Nijmegen, and the swampy border regions in the northeast of the country.

33 The etchings by Ruisdael, Roghman, and Waterloo are thus pendants to the map book of the Netherlands by Joan Blaeu, in the same way that etchings by Visscher, the Van de Veldes, and Bloemaert relate to the maps of Holland from the first decade.

\section{Imitation and Invention}

34 As attractive as this reasoning may be, one wonders whether it offers sufficient explanation for the almost fanatical enthusiasm with which so many Dutch artists focused on the reproduction of a specific piece of the natural world. This desire for the accurate depiction of specific locations also existed among the public. That appears evident, for example, from the custom of including the name of the place depicted in the representation. That bit of information would seem to have fulfilled the public's wishes, even when the artist did not find it necessary to name the subject. Sometimes this only took place in the second or third edition, while at other times the publisher appears to have made an error-or simply made something up.

35 Even print series that included no specific place names often included the phrase "from life" on the title page, a statement that doubtless was intended as an endorsement. It was thus not always the case that the landscape was a directly recognizable place. Evidently, it was sufficient on the part of the buyer to know that the lovely picture he had before his eyes in print form rendered a part of the existing world. In such a case, it was not the specific location that was essential but rather the veracity of the depiction.

36 Although sometimes the artist did not indicate the location in so many words, it has still been possible to identify it. Even with such "anonymous" landscapes, it is remarkable how often the artist ostensibly wanted to achieve an accurate depiction of his subject. This is evident from his process. More than once, he took the trouble to etch his subject-which he had first drawn from life in nature-in mirror image on the copper plate. The image was then restored by printing it onto paper.

37 Even artists whom we would not expect to work in this manner did so. For example, Hercules Segers "remirrored" his View of Amersfoort (fig. 22, cat. 32) with the same care as the view from his own window in another etching. Roghman's large etchings of views in and near The Hague Forest (fig. 23, cat. 50) do not represent any easily identifiable location and thus it would have been difficult for the viewer to be sure of their veracity. Nevertheless, Roghman printed them in the correct orientation as evidenced by the extant preparatory drawings. In this case, the inclusion of "drawn from life" on the title page must be taken very seriously. 


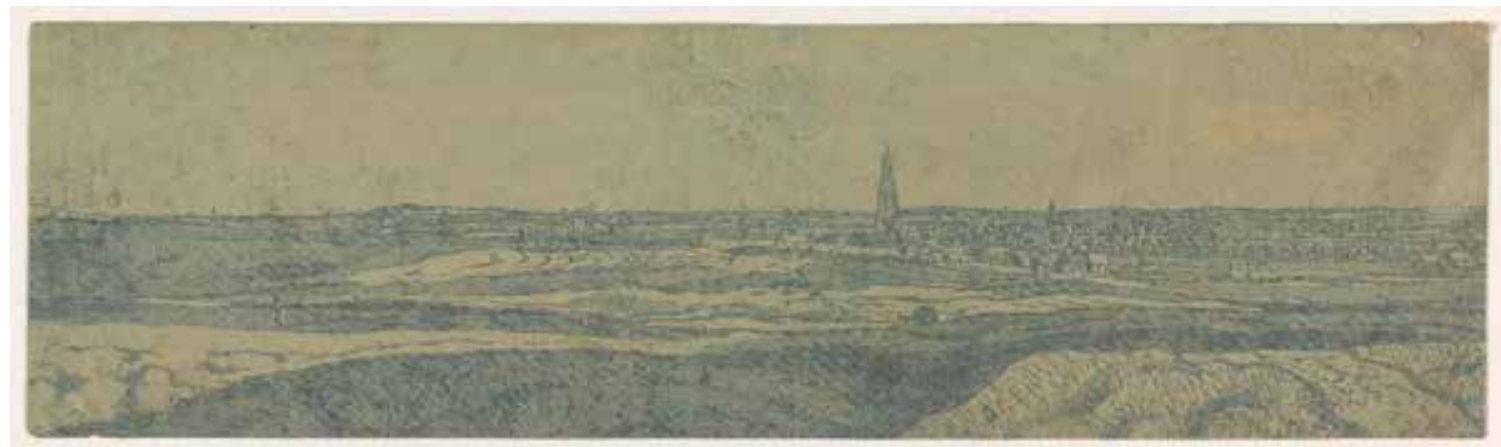

Fig. 22 Cat. 32, Hercules Segers, (Haarlem 1589/90-1638 The Hague?), View of Amersfoort, ca. 1630,etching and drypoint, single state

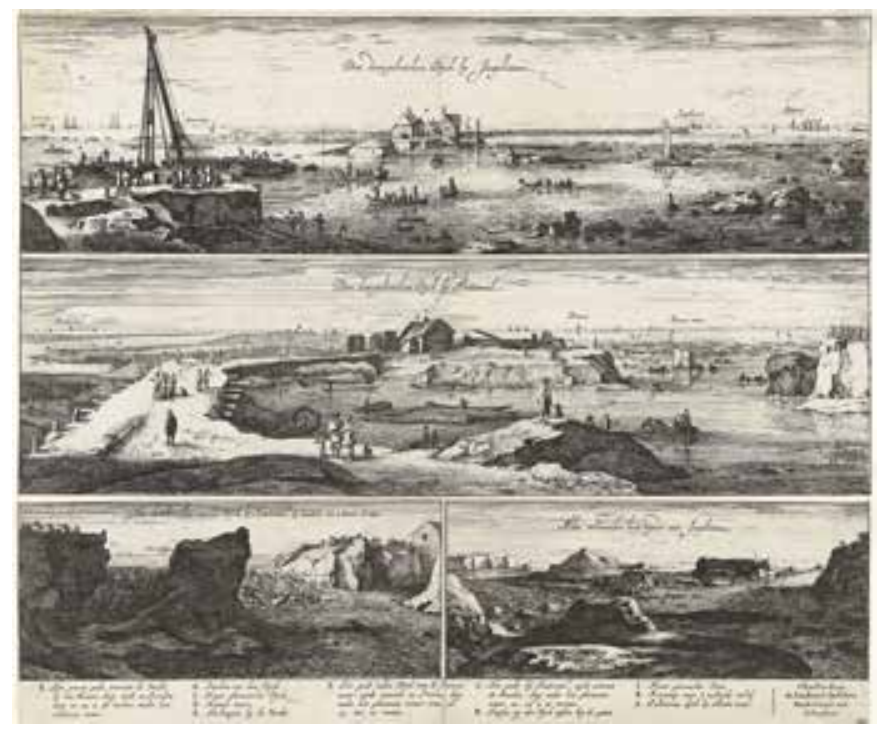

Fig. 23 Cat. 50, Roelant Roghman, (Amsterdam 1627-1692 Amsterdam), The Breach in the Dike between Amsterdam and Diemen in 1651, 1651, etching, single state

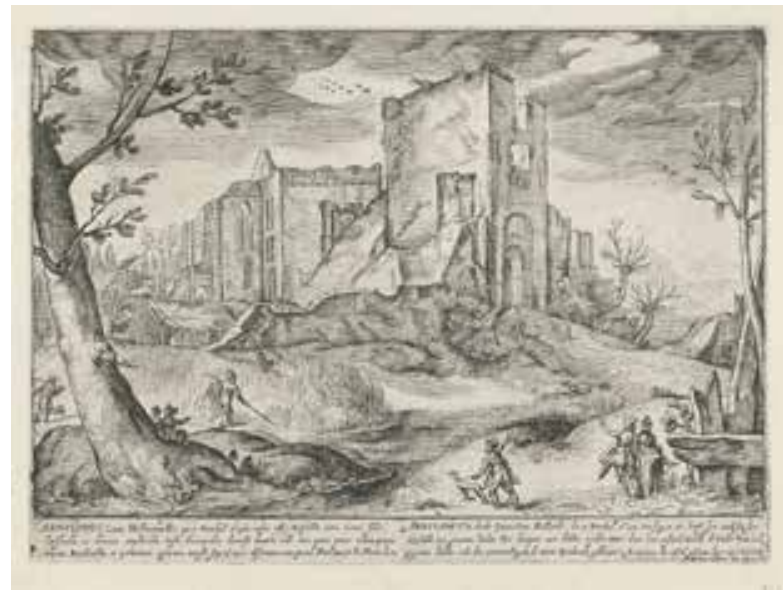

Fig. 24 Cat. 4, Gerrit Adriaensz Gouw, (Haarlem ca. 1590-1638 Haarlem), The Ruins of Brederode (astle, ca. 1610, etching, retouched with a burin, second state (2)

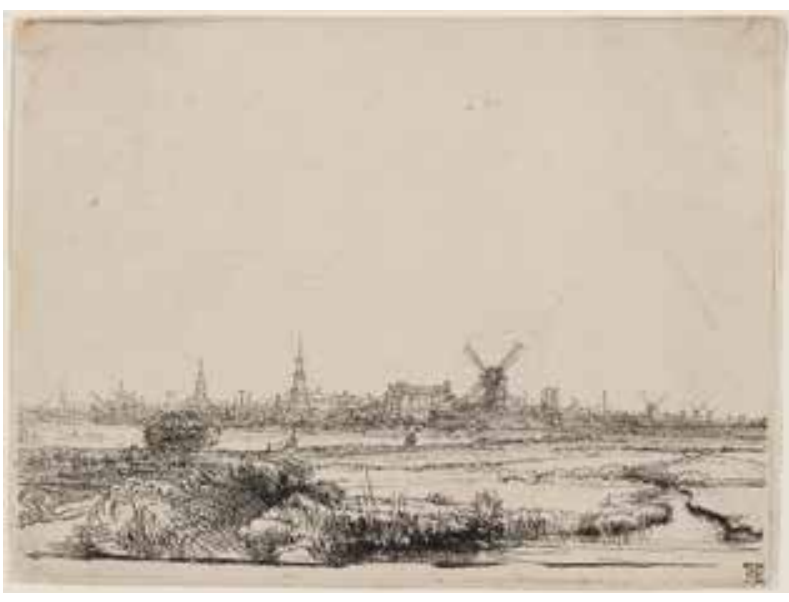

Fig. 25 Cat. 33, Rembrandt, (Leiden 1606-1669 Amsterdam), View of Amsterdam from the East (mirror image), 1640-42, etching, single state

Not all of the landscape prints from life were "remirrored" by the artist. The View of Brederode by Gerrit Gouw after Jacob Matham (fig. 24, cat. 4) is in mirror image, as is evidenced by Hendrick 
Goltzius's sketch made at that location, which served as the point of departure for the preliminary drawing of the etching. As demonstrated by the caption, this may be due primarily to the ruins' status as the object of historical consideration. Rembrandt printed his View of Amsterdam (fig. 25 , cat. 33) in mirror image without hesitation. In his case, he was apparently more interested in evoking the atmosphere of the city and the impression it made on him while he wandered through it than in producing an accurate portrait. However, even the series of villages along the Lek, etched after drawings by Herman Saftleven, which are properly furnished with place names, were printed in mirror image (figs. $26 \mathrm{a}-\mathrm{f}$, cats. $70 \mathrm{a}-\mathrm{f}$ ). We may conclude that rendering scenes as faithfully as possible and basing them on in situ study often, although not always, played a decisive role in an artwork's realization.
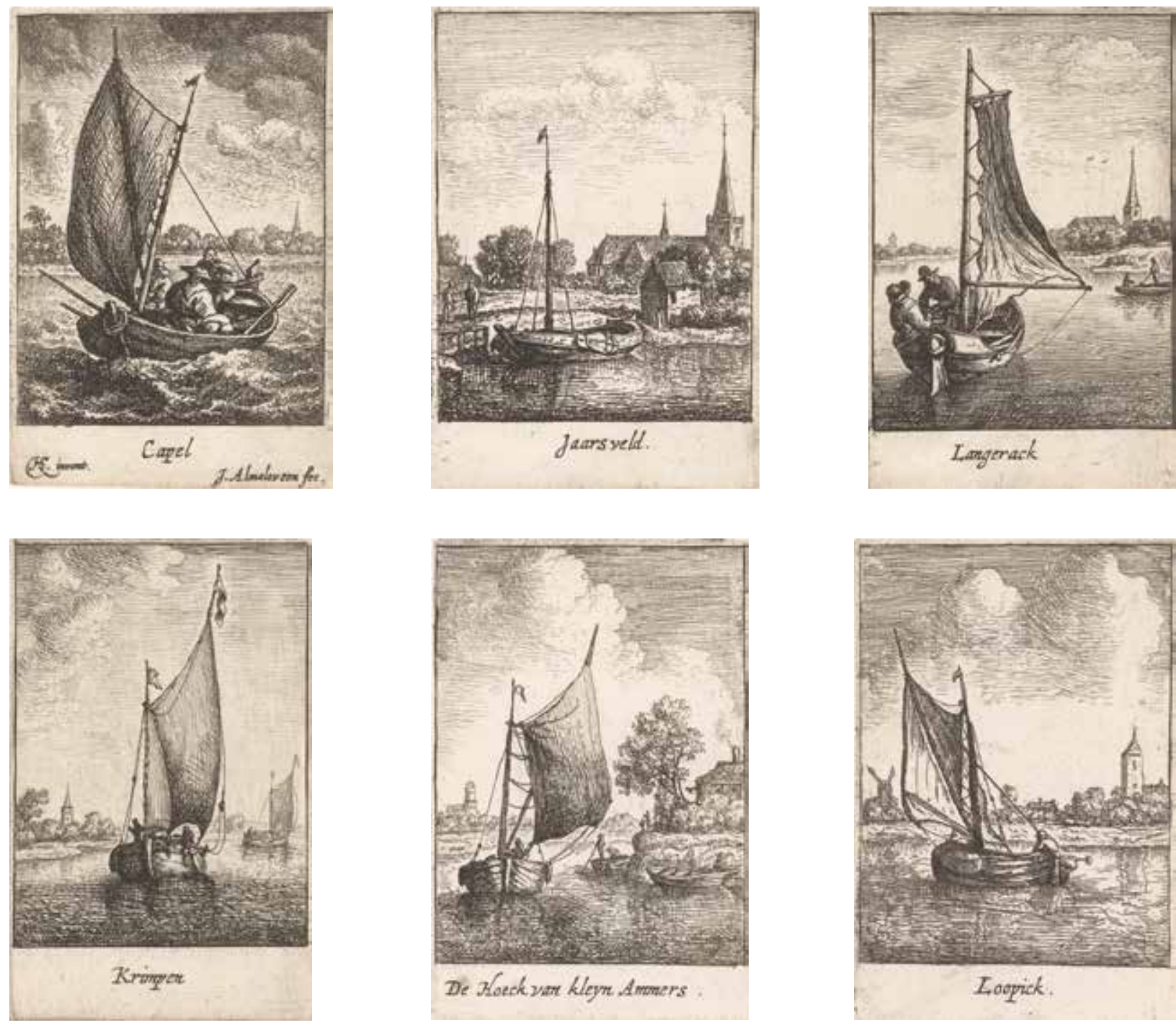

Fig. 26a-f Cat. 70a-f, Jan van Almeloveen, (Mijdrecht ca. 1652-after 1683 Utrecht?), Six Places along the Lek and the Lopiker Wetering, (left to right, top to bottom, Lopikerkapel, Jaarsveld, Langerak, Krimpen, Klein Ammers, Lopik, ca. 1680, etching, first state (2)

To understand this we have to return to Renaissance ways of thinking about art. ${ }^{13}$ The great artists and thinkers of the Renaissance were seized by the rediscovered riches of the natural world 
created by God. They were convinced that the visual arts should not be based in the pious and faithful depiction of preexisting images, but rather through studying the divine nature surrounding us. Only through profound awareness of creation - the human body, plants, and animals and the landscape-could the artist recreate these elements in the form of a work of art. Leonardo da Vinci even went so far as to consider painting as a science that examines the visible world empirically and demonstrates the result of this inquiry to the viewer. The sole task of the painter is "l'imitazione di esse opera di natura," (the imitation of the works of nature), but then at the highest conceivable level and in the best possible form. That form is in principle present in nature; the task of the artist is simply to "find" it. Thus for Da Vinci, the idea that art is an "invention" lies in the concept of the artwork being "found" by the artist.

According to this line of thought, the artist does not just provide an image of nature as it appears to the eye, but rather he follows nature in her working methods as well. In a certain sense, in "recreating" nature, he not only imitates the work of the Creator but also how the Creator himself works. The following statement by Michelangelo illustrating the same line of thought has been handed down: "A good painting is nothing more than the reflection of the perfections of God and a recollection of his painting."

41 Also north of the Alps, serious reflection took place regarding the artist and his position with regards to nature. Albrecht Dürer stressed that nature is the only paragon for the artist: "One must take care not to make anything beyond human power that nature cannot bear." And also: "The more precise your work is in its form in accordance with real life, the better the work will appear. And this is true!" At the same time, Dürer was of the opinion-just like his Italian contemporaries - that the artist, in regard to the human figure, had to choose the best elements from the multitude of existing forms and compose "something good" from them. ${ }^{14}$

In summary, it can be said that for Renaissance masters, artists carried out their work between two poles: "imitatio" (imitation) and "inventio" (creativity). Since these two poles stood in constant tension with one another, artists and theoreticians of art sometimes took it one way, sometimes another way.

43 In the course of the sixteenth century, younger artists and writers, among them Michelangelo's friend Giorgio Vasari, attempted to elaborate the thoughts of their great predecessors into a more or less systematic theory of the art of painting. ${ }^{15}$ At this point, any mention of divine aspirations ceases to exist. "Divino" was applied primarily to the great masters of the Renaissance. On the other hand, very little survived of the central position that the "imitatio naturae" initially had. In Vasari's opinion and that of his colleagues, the young artist must indeed begin by studying and copying human and other natural beings, but in addition, the art of antiquity and the art of the great masters of the present day, that is, the Italian Renaissance, come to the fore as equally important examples.

44 Moreover, not everything in nature was considered suitable. The artist had to carefully select the best elements and implement them in the artwork. That selectivity had also formed an element within the thought of their venerable predecessors. But for Vasari, the emphasis was no longer on "imitatio"- as for Leonardo and Michelangelo-but entirely on the individual invention of the 
artist. That formed the basis for the realization of the artwork. The artist thus improved nature with help from his discriminating judgment and his invention.

Some Italian theorists from Vasari's time did not go as far in suppressing the natural element in favor of the theoretical standard. Vincenzo Danti, himself a student of Michelangelo, agreed with Vasari that in principle the artist serves to represent things in their most perfect form, that is, as they should be. He did not, however, assume in advance that nature is imperfect. He thus made a distinction between what he called the "due strade" (the two paths) that the artist can choose. One way is that of "ritrarre" (accurately drawing or portraying things that are good in nature). The second path is that of "imitare" (imitating nature in its structure). The artist had to follow this course so that what comes across as an imperfect form in nature is portrayed in perfect form. In short, in the first case, there was mention of "imitating," and in the second of "emulating." With this line of thinking, it can be said that Danti succeeded in creating a bridge between how art was conceptualized in the Renaissance and the artistic practice of the seventeenth century. ${ }^{16}$

46 Vasari's "Lives" and the theories he worked through exerted a great influence on later writers on art, among them Karel van Mander from Haarlem. ${ }^{17}$ Nevertheless, the elements van Mander chose to emphasize differ. Working "from life," that is from nature, had great significance for him. Furthermore, he had much more interest in landscape than Vasari. Moreover, van Mander was humbler than his Italian role model with regard to the artist's place and ability. He always left off the addition of "divine" when referring to Michelangelo. He no longer mentioned the artist as a "God-like creator." For van Mander, the artist may well be an "ape of nature," but his "mimicking" did not refer so much to the imitation of nature in its creative and formative function-as was still the case for Danti-but rather the faithful rendering of the visible world.

47 However, van Mander did realize that a good artist also contributes something or makes something new: "Life must sometimes receive assistance from the understanding of art." Yet, "the artful painters are indebted to the generous nature that serves perpetually as a model for them." In his position regarding nature and its significance for art, van Mander was thus less self-assured than his Italian predecessor. One gets the impression that for him the artist will always inhabit a subordinate role vis-à-vis creation: "The living world, or nature, always wants to put painting to shame." 18

At the same time, van Mander was in many aspects - as evidenced by his own works - a true disciple of the Italian ways of thinking in the Late Renaissance: the artist indeed imitates nature in the elemental components, but his own invention determines the quality of the artwork to a great extent. For van Mander, there was a certain ambivalence and that is not so surprising. Since time immemorial, a very important aspect of the artist's profession in the Netherlands had involved working "from life." In addition, in the course of the sixteenth century very different ideas had started to play a role in Netherlandish artists' thinking about art and nature. These ideas greatly influenced theory and practice in the visual arts of the seventeenth century.

\section{Reformation and Counter-Reformation}


as the misuse of art for unholy objectives, in particular in the church. This involved "papal superstitions," such as the worship of icons, but also the danger of a pagan morality from antiquity. This resulted in the infiltration of vices like pride, intemperance, and indecency in the depiction of biblical stories, martyrs, and saints.

50 A point of principle was the question of whether the sacred could be depicted at all. John Calvin was the most acerbic and firmest in his belief on this issue. ${ }^{19}$ Appealing to the Second Commandment, he not only rejected any attempt at representing the invisible but also any depiction of visible things that could provoke unwanted worship, especially in church buildings. Calvin's religious doctrine served as the justification for the Great Iconoclasm of 1566. Also in a less drastic sense, it led to the use of almost exclusively non-figurative and decorative art in Calvinist churches. Calvin was, however, neither averse to art in general, nor to the depiction of biblical stories. Yet he did stipulate that they must always have an uplifting character and pedagogical value.

51 Calvin also made a positive contribution-in addition to a counteractive inhibitive one-to the practice of the visual arts. He strongly emphasized that the world is essentially neither wicked nor reprehensible but rather the earthly reflection of paradise and as such worthy to be studied with great attention. According to Calvin, humankind has the mandate to achieve this. His doctrine proved to be a powerful stimulus toward inquiry in the field of natural science but also- relevant here-for the study of history and geography. At the beginning of the seventeenth century, many of the most important Dutch cartographers, makers, and publishers of cartographical and topographical works, were devout Calvinists, among them Claes Jansz Visscher. There is good reason to assume that for Visscher and his fellow believers/artists, the precise study and depiction of the world in all its aspects had a clearly pious significance - whether in the form of a map, townscape, historical print, or a series depicting regional costumes.

It is remarkable how closely Calvin's doctrine in this respect connects to Renaissance artists' notions regarding nature. Praise for visible reality and the call to study it resonated among those circles as well. Leonardo was the first to describe painting as a science long before Calvin's followers brought it into practice in the Netherlands.

53 The Protestant church reformers were not the only ones to oppose the uninhibited treatment of sacred history as well as pride and indecency in art. The Council of Trent, which convened from 1545 to 1563 , drew up a number of strongly restrictive rules for the iconography of altarpieces and other forms of religious painting. These guidelines revealed not only a high degree of prudishness but also a consistent dedication to the historical veracity of the imagined history and authenticity of the depiction..$^{20}$ The doctrine of the Counter-Reformation is reflected in the oftread tracts by theologians-Jan van der Meulen or Molanus from Leuven, among others-with concrete instructions for the decoration of church buildings and, in particular, for altarpieces. This doctrine also exerted an impact on art literature, as is evidenced by the popular book from 1585 by the painter Gianpaolo Lomazzo. The author of this short work makes no claim regarding painting's capacity to improve nature, for it would be sinful to presume that something more perfect in the world was conceivable. The artist receives from him the categorical command to focus on God's creation, and nothing more than that. ${ }^{21}$ 
54 Evidence exists that the Council of Trent had consequences for artistic practice more far-reaching than is usually assumed. Respect for God's creation as a standard for every form of painting combined with the fear of all-too-human delusions to exert an effect even on landscape paintings hung in Roman Catholic churches-in particular in the Southern Netherlands. A painted landscape was intended to take on the function of a devotional piece in order to shape the thoughts of the faithful. Otherwise, it is difficult to explain why so many churches in Flemish and Brabant cities are mentioned as having landscapes that served as altarpieces. ${ }^{22}$

55 Now the contours of a view of art that was professed in more or less orthodox Christian circles of different denominations becomes visible. In this view, the notion of a work of art being "from life" was not a neutral piece of information but rather a declaration of genuineness, of authenticity, or a sign of particular quality and reliability. It is remarkable how many series of landscape prints are provisioned with this hallmark on the title page. Sometimes the artist or the publisher went a step further. He did not simply call the work "getekend naar 't leven" (drawn from life), but "geconterfeit naar 't leven" (portrayed from life). This apparently superfluous addition becomes significant when we recall that "imitatio naturae" in the classical sense could be interpreted in two ways: as "representation" and as "imitation." It appears that the assertion "portrayed," for orthodox Protestants and Catholics in the seventeenth century emphasized that the artist acted not as an independent creator but rather as a humble portraitist of God's creation.

The tension between art and life, between the artist as portraitist and as "God-like creator," accompanied discussions of art as an undercurrent throughout the entire seventeenth century. The Calvinist/humanist Constantijn Huygens Sr. summarized the orthodox perspective in his poem Oogen-Troost (Consolation for the Eyes):

Go stroll with them through woods and hills and dales, That, they say, is a picture-like (schilderachtig) view.

Me thinks they are saying: God makes ingenious copies Of our originals ... ${ }^{23}$

The word schilderachtig can be understood in this context in two ways: "something for a painter" or "it looks like a painting!" It is clear that Huygens wanted to challenge the second interpretation here. He introduced it as a joke, but the tenor is clear. The painter is nothing more than a copyist; don't let him forget that! Even after the middle of the century, when the modern, rigorous French version of Vasari and his contemporaries' theories of art was enlisted and defended with conviction in the Republic's refined and aristocratic circles, the authority of the orthodox dogma still remained unbroken. In 1670, the painter Willem Goeree published his Inleydingh tot de practijck der al-gemeene schilder-konst (Introduction to the Practice of the General Art of Painting). At the very beginning of the book, he dedicated a chapter to "t Woort Schilderachtigh qualijck gebruyck" (the improper use of the word "schilderachtigh"). First, he established that all efforts on the part of art to offer more than nature ultimately indicate a lack of ability. According to Goeree it thus follows that when we call something in nature explicitly schilderachtig, we use that word improperly. We act then, in these instances, as if the creation should imitate art, "as if the creatures were merely almost as charming, elegant, and pleasant as the painted things." The things created in nature are far exalted in every aspect above those that are painted, let there be no doubt. He 
then, for the sake of completeness, cited Huygens's previously mentioned rules. ${ }^{24}$

57 It was not any different for Rembrandt's student Samuel van Hoogstraten in his Introduction to the High School of the Art of Painting: Or, the Visible World from 1678. For the forewarned reader, the second title speaks volumes. At the beginning, the book discusses the purpose of painting: "Painting is a science for depicting all ideas, or mental images that the entire visible world can provide" [please note: not the ideas in the mind of the artist! BB]. Then he repeats once again in the margin: "Painting is to represent nature." And moreover: "For a perfect painting is like a mirror of nature, making things that are not appear to be [that is, that are not actually in existence, but in painted form], and deceiving in a permissible, diverting and commendable way." ${ }^{25}$

After he points out the limitations of art at the beginning of the book, he discusses at the end of the last chapter the question of whether painting in such a manner should actually be allowed. First, he expounds on the adulation that has indeed accrued sometimes to paintings. After once again quoting Psalm 115, in which idolaters are derided, he cites John Calvin as the utmost authority with a long quote demonstrating that even Calvin - albeit under certain conditionsgrants painting a worthy place in the culture: "And the majesty of God, which is far beyond the reach of any eye, must not be dishonored by unbecoming representations. The only things, therefore, which ought to be sculpted or painted are things that the eye may comprehend. Such may be Histories, which are of some use for instruction or admonition: or physical things, which signify nothing and consequently serve no purpose other than to please the eye."26

In a number of instances, Van Hoogstraten shows himself to be a confirmed disciple of stringent classicism with its rather scant regard for nature as the basis for art. Yet, as we have seen above, he begins his book by professing his faith in the tradition of imitatio (from life) as succinctly as possible. And not only that, on concluding his work he even tries to give the imitation of nature a religious foundation by invoking Calvin as a witness. Given this line of thinking, painting from life is not only a matter of scientific purity but also of Christian orthodoxy-and that in the last quarter of the century, when Calvinism's influence was seemingly declining. This points us again to the fact that thinking about art in the course of the whole seventeenth century was largely determined by the question: from life, or not?

Seventeenth-century landscape artists also remained faithful to the mandate that natural reality alone served as a guide. If artists are successful in representing their subject entirely accurately and thereby offer it as a work of art, then that is all the more an endorsement. Even if they handle motifs derived from nature more freely, their representations may at times be dubbed "from life." "Life"-visible reality that is revealed in nature-is actually for the seventeenth-century artist never a supplier of randomly applicable motifs, but on the contrary, the only fixed point of reference and ultimately the highest standard of artistic quality.

\section{Conclusion}

61 This article posited at the beginning that feelings of national pride probably played a particular role in the artists' and public's preference for their own landscape. Next to this, we found an intense curiosity regarding the essence of things in nature. This had flourished in the Renaissance 
and was subsequently nourished by a new, world-embracing piety and justified by the mandate to examine God's creation. Thirdly, a strong, indigenous artistic tradition existed that proceeded from reality as a model and standard. This was noticeably strengthened by the orthodox dogma that opposed too much fantasy in the visual arts. It thus becomes understandable how in the landscape art of the Netherlands, the emotional involvement in one's own environment became bound to the demand for authenticity in representation: the Netherlands drawn from life.

\section{EDITOR'S NOTE}

Boudewijn Bakker served as director of Museum Het Rembrandthuis but worked for most of his professional career at the Stadsarchief Amsterdam. Much of his research has focused on the intellectual history of landscape art, culminating in the important book, Landscape and Religion from Van Eyck to Rembrandt (Aldershot: Ashgate, 2012; first, Dutch edition 2004). Some other relevant titles are:

'Schilderachtig: discussions of a seventeenth-century term and concept', in Simiolus 23 (1995), p. 147-162. https://doi.org/10.1163/187501793X00135

Landscapes of Rembrandt: His Favorite Walks, with Mària van Berge-Gerbaud, Erik Schmitz, and Jan Peeters. Bussum: Thoth/Amsterdam: Gemeentearchief/Paris: Fondation Custodia, 1998.

"Nature or Art? Rembrandt's Aesthetics and the Dutch Tradition." In Rembrandt's Landscapes, edited by Christiaan Vogelaar and Gregor J. M. Weber, 144-71. Leiden: Stedelijk Museum de Lakenhal/Kassel: Staatliche Museen/Zwolle: Waanders, 2006.

Het aanzien van Amsterdam: Panorama's, plattegronden en profielen uit de Gouden Eeuw, with Erik Schmitz. Amsterdam and Bussum, 2007.

"Portraits and Perspectives: Townscape Painting in Seventeenth-Century Holland." In Dutch Cityscapes of the Golden Age, edited by Ariane van Suchtelen, 34-59. The Hague: Mauritshuis/ Washington, D.C.: National Gallery of Art/Zwolle: Waanders, 2008-9.

“Au vif-naar't leven - ad vivum; The Medieval Origin of a Humanist Concept." In Aemulatio: Imitation, Emulation and Invention in Netherlandish Art from 1500 to 1800; Essays in Honor of Eric Jan Sluijter, edited by Anton Boschloo, Jaquelyn N. Coutre et al., 37-52. Zwolle: Waanders, 2011.

Landscape and Religion from Van Eyck to Rembrandt. Farnham: Ashgate, 2012 (original Dutch edition: 2004) 


\section{Acknowledgements}

I am very grateful to the leadership of the Rembrandthuis for the invitation to write this article. While I was writing, I found support in conversations with Huigen Leeflang and Marleen Slooff and, as I finalized the text, in the editorial care and patience provided by Marlies Enklaar and Ed de Heer. I am very grateful to all of them.

Boudewijn Bakker studied history and art history at the University of Amsterdam. After a few years teaching at the university, he began work at the Stadsarchief Amsterdam (1971 - 2003), first as head of the prints and drawings department, later as head curator for exhibitions and publications, and finally as a guest curator. The topics of some of the exhibitions he organized include Rembrandt's walks around Amsterdam, Dutch landscape prints, townscape painting in Amsterdam and Venice. The Netherlands Institute for Advanced Studies appointed him a fellow in 1995-1996, and from 2000 to 2008 he served as researcher and research coordinator at the Amsterdam Center for the Study of the Golden Age. His doctoral thesis (2003) at the Vrije Universiteit (Free University Amsterdam) appeared as Landscape and Religion from Van Eyck to Rembrandt in 2012. Most recently, he published'Rembrandt and the Humanist Ideal of the Universal Painter' in Stephany Dickey (ed), Rembrandt and his Circle: Insight and Discoveries, Amsterdam (Amsterdam University Press) 2017.

\section{boudewijn.bakker@planet.nl}

Claire C. Whitner holds a Ph.D. in Germanic Languages from the University of California, Los Angeles and currently serves as the Director of Curatorial Affairs/James A. Welu Curator of European Art at the Worcester Art Museum.

clairewhitner@worcesterart.org

\section{List of Illustrations}

Fig. 1 Cat. 1, Josua van den Ende, (Amsterdam ca. 1584-after 1634 Amsterdam), Claes Jansz Visscher, (Amsterdam 1587-1652 Amsterdam), Figurative Map of Holland, 1608, engraving (map) and etching (border decorations and cartouche)

Fig. 2 Cat. 11, Claes Jansz Visscher, (Amsterdam 1587-1652 Amsterdam), Castle Toutenburg at Vollenhove, 1617, (from a series of four prints with medieval castles), etching, second state (2)

Fig. 3 Cat. 12, Claes Jansz Visscher, (Amsterdam 1587-1652 Amsterdam), View of the City and the Castle Gennep, 1641, two etchings on one plate, single state

Fig. 4 Cat. 55, Wenceslas Hollar, (Prague 1609-1677 London), Philippine, ca. 1650, etching, second state (3)

Fig. 5a Cat. 8a, Claes Jansz Visscher, (Amsterdam 1587-1652 Amsterdam), The Lighthouse at Zandvoort, ca. 1611-14, etching, single state 
Fig. 5b Cat. 8b, Claes Jansz Visscher, (Amsterdam 1587-1652 Amsterdam), Bleaching Fields near the Haarlemmer Hout, ca. 1611-14, etching, single state

Fig. 6 Cat. 10, Claes Jansz Visscher, (Amsterdam 1587-1652 Amsterdam), View of Egmond aan Zee, ca. 1615, etching and drypoint, single state

Fig. 7 Cat. 57, Reinier Nooms, called Zeeman, (Amsterdam ca. 1623-1667 Amsterdam), Flooded land in Zeeland, ca. 1656, etching, first state (3)

Fig. 8 Cat. 60, Jan Hackaert, (Amsterdam 1629-after 1685 Amsterdam?), Forest Landscape with Travelers, ca. 1650-60, etching, second state (2)

Fig. 9 Cat. 53, Salomon Saverij, (Amsterdam 1594-1678 Amsterdam), De Rijp before and during the Fire of 1654, ca. 1657, etching, single state

Fig. 10 Cat. 54, Wenceslas Hollar, (Prague 1609-1677 London), Muiderberg, ca. 1643, tching, single state

Fig. 11 Cat. 43, Jacob van Ruisdael, (Haarlem 1628/29 -1682 Amsterdam), Travelers in a Forest Marsh, 1650-55, etching, fourth state (4)

Fig. 12 Cat. 46, Adriaen Verboom, (Rotterdam ca. 1628-ca. 1670 Amsterdam?), Trees in a Bog, ca. 1663 , etching, first state (3)

Fig. 13 Cat. 5, Simon Wynants Frisius, (Harlingen? ca. 1580-1629 The Hague), The Overtoom near Amsterdam, ca. 1650, etching, first state (3)

Fig. 14a Cat. 6a, Hessel Gerrits, (Alkmaar 1581-1632 Amsterdam), After David Vinckboons, (Mechelen 1576-1633 Amsterdam), Two Landscapes with Castles, Nijenrode ("Ver"),etching, first state (2)

Fig. 14b Cat. 6b, Hessel Gerrits, (Alkmaar 1581-1632 Amsterdam), After David Vinckboons, (Mechelen 1576-1633 Amsterdam), Two Landscapes with Castles, Loenersloot ("Aestas"), etching, first state (2)

Fig. 15a Cat. 9a, Claes Jansz Visscher, (Amsterdam 1587-1652 Amsterdam), Four Views outside of Amsterdam, The Karthuizer Klooster (Cartusian Convent), ca. 1610, etching, single state

Fig. 15b Cat. 9b, Claes Jansz Visscher, (Amsterdam 1587-1652 Amsterdam), Four Views outside of Amsterdam, The Amsteldijk by Kostverloren, ca. 1610, etching, first state (2)

Fig. 15c Cat. 9c, Claes Jansz Visscher, (Amsterdam 1587-1652 Amsterdam), Four Views outside of Amsterdam, The Bend in the Road to Amstelveen, ca. 1610, etching, first state (2)

Fig. 15d Cat. 9d, Claes Jansz Visscher, (Amsterdam 1587-1652 Amsterdam), Four Views outside of 
Amsterdam, The Mile Marker at Sloten, ca. 1610, etching, first state (2)

Fig. 16a Cat. 15a, Esaias van de Velde, (Amsterdam ca. 1590 -1630 The Hague), Skaters on the Ice at a Mill near Penningsveer, 1615-16, etching, first state (4)

Fig. 16b Cat. 15b, Esaias van de Velde, (Amsterdam ca. 1590-1630 The Hague), Fort on the Schel$d t, 1615-16$, etching, second state (4)

Fig. 17a Cat. 17a, Willem Buytewech, (Rotterdam 1591-1624 Rotterdam), Landscape with Trees, a Path, and a Wagon, ca. 1616-17, etching, third state (3)

Fig. 17b Cat. 17b, Willem Buytewech, (Rotterdam 1591-1624 Rotterdam), The Sower, ca. 161617, etching, third state (3)

Fig. 18 Cat. 2, Pieter Bast, (Antwerp ca. 1570-1605 Leiden), Profile of Franeker from the Northeast, 1598, engraving, single state

Fig. 19 Cat. 3, Pieter Bast, (Antwerp ca. 1570 -1605 Leiden), Two Blind Men with a View of Veere in the Background, 1598, engraving, second state (2)

Fig. 20 Cat. 20, Jan van de Velde II, (Delft? 1593-1641 Enkhuizen), View of the Hofvijver in The Hague (January), 1618, etching, single state

Fig. 21a Cat. 7a, Boëtius Adams Bolswert, (Bolsward 1580-1633 Antwerp), After Abraham Bloemaert, (Gorinchem 1564-1651 Utrecht), Two Views of the Environment in the Vicinity of Utrecht, Village View in the Fen, 1613-14, etching, first state (2)

Fig. 21b Cat. 7b, Boëtius Adams Bolswert, (Bolsward 1580-1633 Antwerp), After Abraham Bloemaert, (Gorinchem 1564-1651 Utrecht), Two Views of the Environment in the Vicinity of Utrecht, Homestead on the Dunes, 1613-14, etching, first state (2)

Fig. 22 Cat. 32, Hercules Segers, (Haarlem 1589/90-1638 The Hague?), View of Amersfoort, ca. 1630,etching and drypoint, single state

Fig. 23 Cat. 50, Roelant Roghman, (Amsterdam 1627-1692 Amsterdam), The Breach in the Dike between Amsterdam and Diemen in 1651, 1651, etching, single state

Fig. 24 Cat. 4, Gerrit Adriaensz Gouw, (Haarlem ca. 1590-1638 Haarlem), The Ruins of Brederode Castle, ca. 1610, etching, retouched with a burin, second state (2)

Fig. 25 Cat. 33, Rembrandt, (Leiden 1606-1669 Amsterdam), View of Amsterdam from the East (mirror image), 1640-42, etching, single state

Fig. 26a Cat. 70a, Jan van Almeloveen, (Mijdrecht ca. 1652-after 1683 Utrecht?), Six Places along the Lek and the Lopiker Wetering, Lopikerkapel, ca. 1680, etching, first state (2) 
Fig. 26b Cat. 70b, Jan van Almeloveen, (Mijdrecht ca. 1652-after 1683 Utrecht?), Six Places along the Lek and the Lopiker Wetering, Jaarsveld, ca. 1680, etching, first state (2)

Fig. 26c Cat. 70c, Jan van Almeloveen, (Mijdrecht ca. 1652-after 1683 Utrecht?), Six Places along the Lek and the Lopiker Wetering, Langerak, ca. 1680, etching, first state (2)

Fig. 26d Cat. 70d, Jan van Almeloveen, (Mijdrecht ca. 1652-after 1683 Utrecht?), Six Places along the Lek and the Lopiker Wetering, Krimpen, ca. 1680, etching, first state (2)

Fig. 26e Cat. 70e, Jan van Almeloveen, (Mijdrecht ca. 1652-after 1683 Utrecht?), Six Places along the Lek and the Lopiker Wetering, Klein Ammers, ca. 1680, etching, first state (2)

Fig. $26 \mathrm{f}$ Cat. 70f, Jan van Almeloveen, (Mijdrecht ca. 1652-after 1683 Utrecht?), Six Places along the Lek and the Lopiker Wetering, Lopik, ca. 1680, etching, first state (2)

${ }^{1}$ Eddy de Jongh, "Realisme en schijnrealisme in de Hollandse Schilderkunst van de zeventiende eeuw," in Rembrandt en zijn tijd (Brussels: Paleis voor Schone Kunsten, 1971), 61-62.

${ }^{2}$ Edwin Buijsen, Tussen fantasie en werkelijkheid: 17de eeuwse hollandse landschapschilderkunt (Baarn: Stedelijk Museum De Lakenhal Leiden, 1993), 45-52.

${ }^{3}$ Eddy de Jongh, "De iconologische benadering van de zeventiende-eeuwse Nederlandse schilderkunst," in De gouden eeuw in perspectief: Het beeld van de Nederlandse zeventiende-eeuwse schilderkunst in later tijd, ed. Frans Grijzenhout and Henk van Veen (Nijmegen and Heerlen: Open Universiteit, 1992).

${ }^{4}$ Joan Blaeu, Grooten atlas, oft wereltbeschrijving, in welcke 't aaertryck, de zee, en hemel, wordt vertoond en beschreven (Amsterdam 1664).

${ }^{5}$ J. D. H. Harten, "Het landschap in beweging," in Algemene geschiedenis der Nederlanden, ed. Dirk Peter Blok and Michel Cloet (Haarlem: Fubula-Van Dishoeck, 1980); Jan de Vries, "The Dutch Rural Economy and the Landscape," in Dutch Landscape. The Early Years, Haarlem and Amsterdam, 1590-1650, ed. Christopher Brown (London: National Gallery 1986).

${ }^{6}$ Boudewijn Bakker, "Kaarten, boeken, prenten: De topografische traditie in de Noordelijke Nederlanden," in Opkomst en bloei van het Noordnederlandse stadsgezicht in de 17de eeuw/The Dutch Cityscape in the 17th Century and Its Sources (Amsterdam: Amsterdams Historisch Museum/ Toronto: Art Gallery of Ontario, 1977).

${ }^{7}$ Karel van Mander, Het Schilder-Boeck... (Haarlem: Voor Paschier Van Westbusch, 1603-1604), folio 34 of Den Grondt der edel vry schilder-const, chapter 8 on landscape, verse 3.

${ }^{8}$ Konrad Oberhuber, Die Kunst der Graphik IV, Zeischen Renaissance und Barock, Das Zeitalter von Brueghel und Bellange, Werke aus dem Besitz der Albertina (Vienna: Albertina, 1967-68), cat. 10 .

${ }^{9}$ Ibid., cat. 27; see also Boudewijn Bakker, "Levenspelgrimage of vrome wandeling? Claesz Janszoon Visscher en zijn serie 'Plaisante Plaetsen," Oud Holland 107, no. 1 (1993): no. 14. HTTPS://DOI.ORG/10.1163/187501793X00135.

${ }^{10}$ F. W. H. Hollstein, Dutch and Flemish Etchings, Engravings, and Woodcuts, ca. 1450-1700 
(Amsterdam: M. Hertzberger, 1949), 292-317.

${ }^{11}$ Ibid., 216-31.

${ }^{12}$ Ibid., 94-213.

${ }^{13}$ G. F. Hoogewerff, Verbeelding en voorstelling: De ontwikkeling van het kunstbesef (Amsterdam: Wereldbibliotheek, 1938), chapt. 3; Anthony Blunt, Artistic Theory in Italy 1450-1600 (Oxford: Oxford University Press, 1966 [first published 1940]), chapt. 1, 2, and 5; Edgar de Bruyne, Geschiedenis van de aesthetica: De Renaissance (Antwerp and Amsterdam: Philosophische bibliotheek, 1951), sect. 1, chapt. 3.

${ }^{14}$ Hoogewerff, Verbeelding en voorstelling, 60-62.

${ }^{15}$ Ibid., chapt. 4; Julius von Schlosser, Die Kunstliteratur (Vienna: Kunstverlag Anton Schroll \& Co., 1924 [repr. 1985]), Books V, VI.

${ }^{16}$ Hoogewerff, Verbeelding en voorstelling, 65-66; E. K. J. Reznicek, "Realism as a 'Side Road' or 'Byway' in Dutch Art,' in The Renaissance and Mannerism: Studies in Western Art; Acts of the Twentieth International Congress of the History of Art, ed. Millard Meiss (Princeton: Princeton University Press, 1963), 247-53, esp. 252-53.

${ }^{17}$ Hessel Miedema, Karel van Manders Leven der moderne, oft dees-tijtsche doorluchtighe Italiaensche schilders en hun bron (Alphen aan de Rijn: Canaletto, 1984).

${ }^{18}$ Ibid., 61-62.

${ }^{19}$ Marc de Klijn, De invloed van het Calvinisme op de Noord-Nederlandse landschapschilderkunst 1570-1630(Apeldoorn: De Zwijgerstichting, 1982); Boudewijn Bakker, "Levenspelgrimage of vrome wandeling?" 106-9.

${ }^{20}$ Schlosser, Die Kunstliteratur, 378-84.

${ }^{21}$ Hoogewerff, Verbeelding en voorstelling, 66-67.

${ }^{22}$ J. Bruyn, "Op zoek naar een bijbelse interpretatie van zeventiende-eeuwse Nederlandse landschapsschilderijen," in Onze meesters van het landschap (Amsterdam: Rijksmuseum, 1987), no. 61 (with a different interpretation).

${ }^{23}$ Constantijn Huygens, De gedichten: Naar zijn handschrift (Groningen: J. A. Worp, 1892-99) [Translator's note: translation taken from Boudewijn Bakker, "Schilderachtig: Discussions of a Seventeenth-Century Term and Concept," Simiolus: Netherlands Quarterly for the History of Art 23, nos. 2/3 (1995): 153. HTTPS://DOI.ORG/10.1163/187501793X00135

${ }^{24}$ Willem Goeree, Inleydingh tot de practijck der al-gemeene schilder-kunst (Middelburg, 1670), 21. [Translator's note: Translation taken from Bakker, Schilderachtig, 154.] HTTPS://DOI. ORG/10.1163/187501793X00135

${ }^{25}$ Samuel van Hoogstraten, Inleyding tot de Hooge School der Schilderkonst, anders de Zichtbaere Werelt(Rotterdam, 1678 [repr. 1969]), 24-25. [Translator's note: Translation taken from Thijs Weststeijn, The Visible World: Samuel van Hoogstraten's Art Theory and the Legitimation of Painting in the Dutch Golden Age (Amsterdam: Amsterdam University Press, 2008), 86.]

${ }^{26}$ Hoogstraten, Inleyding tot de Hooge School der Schilderkons, 358-59. Translation of quote taken from Weststeijn, The Visible World, 110.

\section{Bibliography}

Bakker, Boudewijn. "Kaarten, boeken, prenten: De topografische traditie in de Noordelijke Nederlanden." In Opkomst en bloei van het Noordnederlandse stadsgezicht in de 17de eeuw/The 
Dutch Cityscape in the 17th Century and Its Sources, 66-75. Amsterdam: Amsterdams Historisch Museum/Toronto: Art Gallery of Ontario, 1977.

Bakker, Boudewijn. "Levenspelgrimage of vrome wandeling? Claesz Janszoon Visscher en zijn serie 'Plaisante Plaetsen.” Oud Holland 107, no. 1 (1993): 97-115. HTTPS://DOI. ORG/10.1163/187501793X00135

Bakker, Boudewijn. "Schilderachtig: Discussions of a Seventeenth-Century Term and Concept." Simiolus: Netherlands Quarterly for the History of Art 23, nos. 2/3 (1995): 147-62. HTTPS://DOI. ORG/10.2307/3780826

Blaeu, Joan. Grooten atlas, oft wereltbeschrijving, in welcke 't aaertryck, de zee, en hemel, wordt vertoond en beschreven. Amsterdam: 1664.

Blunt, Anthony. Artistic Theory in Italy 1450-1600. Oxford: Oxford University Press, 1966. First published 1940.

Bruyn, J. "Op zoek naar een bijbelse interpretatie van zeventiende-eeuwse Nederlandse landschapsschilderijen.” In Onze meesters van het landschap. Amsterdam: Rijksmuseum, 1987.

Bruyne, Edgar de. Geschiedenis van de aesthetica: De Renaissance. Antwerp and Amsterdam: Philosophische bibliotheek, 1951.

Buijsen, Edwin. Tussen fantasie en werkelijkheid: 17de eeuwse hollandse landschapschilderkunt. Baarn: Stedelijk Museum De Lakenhal Leiden, 1993.

De Jongh, Eddy. "De iconologische benadering van de zeventiende-eeuwse Nederlandse schilderkunst." In De gouden eeuw in perspectief: Het beeld van de Nederlandse zeventiende-eeuwse schilderkunst in later tijd, edited by Frans Grijzenhout and Henk van Veen, 299-329. Nijmegen and Heerlen: Open Universiteit, 1992.

De Jongh, Eddy. "Realisme en schijnrealisme in de Hollandse Schilderkunst van de zeventiende eeuw." In Rembrandt en zijn tijd, 143-94. Brussels: Paleis voor Schone Kunsten, 1971.

Goeree,W. Inleydingh tot de practijck der al-gemeene schilder-kunst. Middelburg, 1670.

Harten, J. D. H. "Het landschap in beweging." In Algemene geschiedenis der Nederlanden, edited by Dirk Peter Blok and Michel Cloet, vol. 5, 38-79. Haarlem: Fubula-Van Dishoeck, 1980.

Hollstein, F. W. H. Dutch and Flemish Etchings, Engravings, and Woodcuts, ca. 1450-1700. Amsterdam: M. Hertzberger, 1949.

Hoogewerff, G. F. Verbeelding en voorstelling: De ontwikkeling van het kunstbesef. Amsterdam: Wereldbibliotheek, 1938. Hoogstraten, Samuel van. Inleyding tot de Hooge School der Schilderkonst, anders de Zichtbaere Werelt. Rotterdam, 1678. Reprint 1969. 
Huygens, Constantijn. De gedichten: Naar zijn handschrift. Groningen: J. A. Worp, 1892-99.

Klijn, Marc de. De invloed van het Calvinisme op de Noord-Nederlandse landschapschilderkunst 1570-1630. Apeldoorn: De Zwijgerstichting, 1982.

Mander, Karel van. Het Schilder-Boeck... Haarlem: Voor Paschier Van Westbusch, 1603-4.

Miedema, Hessel. Karel van Manders Leven der moderne, oft dees-tijtsche doorluchtighe Italiaensche schilders en hun bron. Alphen aan de Rijn: Canaletto, 1984.

Schlosser, Julius von. Die Kunstliteratur. Vienna: Kunstverlag Anton Schroll \& Co., 1924. Reprint 1985.

Vries, Jan de. “The Dutch Rural Economy and the Landscape." In Dutch Landscape: The Early Years, Haarlem and Amsterdam, 1590-1650, edited by Christopher Brown, 79-86. London: National Gallery, 1986.

Weststeijn, Thijs. The Visible World: Samuel van Hoogstraten's Art Theory and the Legitimation of Painting in the Dutch Golden Age. Amsterdam: Amsterdam University Press, 2008.

Recommended Citation:

Boudewijn Bakker, Claire C. Whitner (translator), "The Netherlands Drawn from Life: An Introduction*," Journal of Historians of Netherlandish Art 10:2 (Summer 2018) D0I: 10.5092/jhna.2018.10.2.4 